PEN REARING AND IMPRINTING

\title{
OF FALL CHINOOK SALMON
}

Annual Report 1984

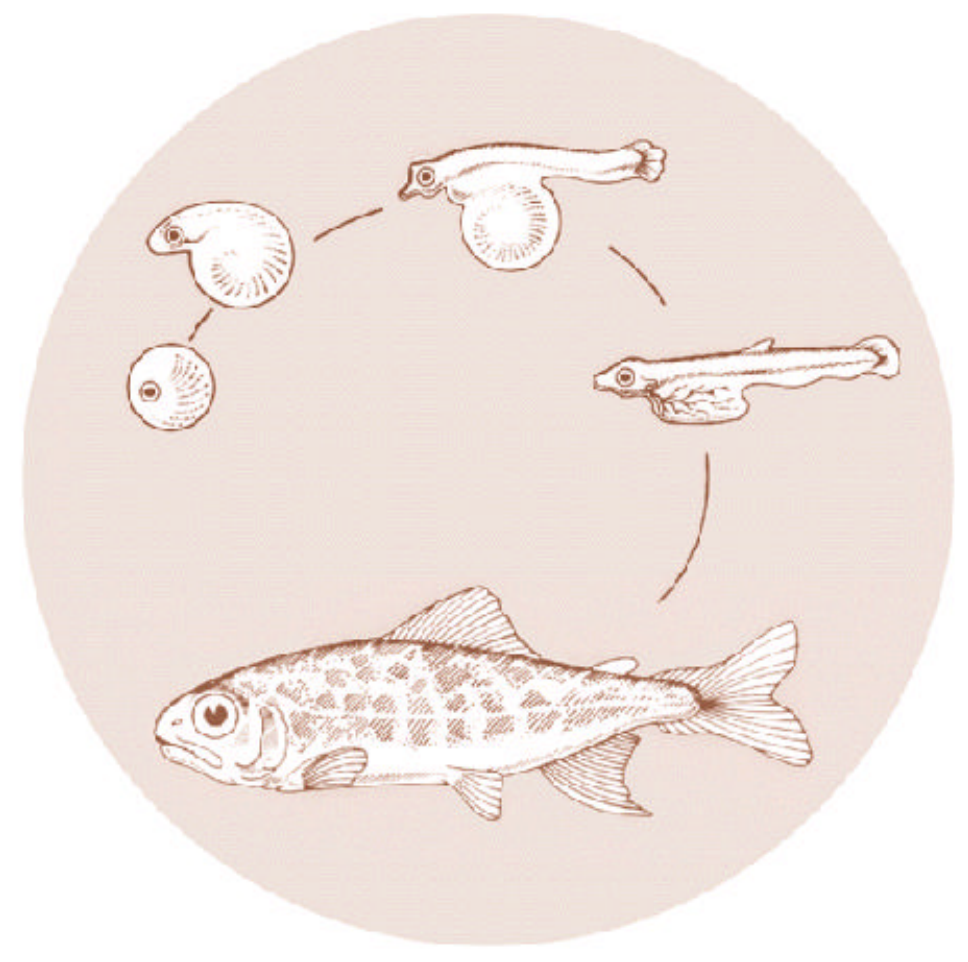

DOE/BP-13084-1 
This report was funded by the Bonneville Power Administration (BPA), U.S. Department of Energy, as part of BPA's program to protect, mitigate, and enhance fish and wildlife affected by the development and operation of hydroelectric facilities on the Columbia River and its tributaries. The views of this report are the author's and do not necessarily represent the views of BPA.

This document should be cited as follows:

Novotny, Jerry F., Thomas L. Macy, and James T. Gardenier, William R. Nelson, Curtis L. Burley - U.S. Fish and Wildlife Service, Pen Rearing And Imprinting Of Fall Chinook Salmon Annual Report 1984, Report to Bonneville Power Administration, Contract No. 1983BP13084, Project No. 198331300, 59 electronic pages (BPA Report DOE/BP-13084-1)

This report and other BPA Fish and Wildlife Publications are available on the Internet at:

\section{http://www.efw.bpa.gov/cgi-bin/efw/FW/publications.cgi}

For other information on electronic documents or other printed media, contact or write to:

Bonneville Power Administration Environment, Fish and Wildlife Division

P.O. Box 3621

905 N.E. 11th Avenue

Portland, OR 97208-3621

Please include title, author, and DOE/BP number in the request. 


\title{
ANNUAL REPORT
}

1984

\section{PEN REARING AND IMPRINTING OF FALL CHINOOK SALMON}

\author{
Jerry F. Novotny, Thomas L. Macy, and James T. Gardenier
}

Project Leaders

William R. Nelson

Curtis L. Burley

\author{
U.S. Fish and Wildlife Service \\ Seattle National Fishery Research Center \\ Willard Field Station \\ and \\ Vancouver Fishery Assistance Office
}

Prepared for

Bonneville Power Administration

Interagency Agreement No. DE-A179-83BP13084

March 1985 


\section{TABLE OF CONTENTS}

\section{$\underline{\text { Page }}$}

List of Figures $\quad$ i i

List of Tables $\quad$ i i i

Abstract 1

Introduction 2

Methods 3

Results $\quad 7$

$\begin{array}{ll}\text { Water Quality } & 7\end{array}$

Zooplankton Abundance $\quad 7$

Rearing of Fed Fish in Pens $\quad 10$

$\begin{array}{ll}\text { Densities } & 10\end{array}$

$\begin{array}{ll}\text { Mortality } & 10\end{array}$

$\begin{array}{ll}\text { Weight } & 14\end{array}$

$\begin{array}{ll}\text { Growth Rates } & 18\end{array}$

Conversion Rates 19

Gill ATPase and Lipid Levels $\quad 22$

Rearing of Unfed Fish in Barrier Net and Pens 22

Discussion and Conclusion $\quad 29$

Acknowledgements $\quad 34$

References Cited $\quad 35$

Appendices 38

Summary of Expenditures for 1984 


\section{LIST OF FIGURES}

Number

Page

1. Recommended hatchery pond loading densities at various temperatures using single pass and recirculated water (Wedemeyer et al. 1981). Maximum recommmended loading densities for Spring Creek Hatchery and for off-station net pen enclosures and actual loading densities in high density pens at Rock Creek and Social Security Pond in 1984 are indicated

2. Mortality rates of fed fish at Social Security Pond and Rock Creek at temperatures encountered during 1984 rearing trials

3. Weekly mortality rates of fed fish at Social Security Pond and Rock Creek, 1984 A -"acceptable" mortality at high density; B -- "acceptable" mortality at low density) 16

4. Total pounds of fish produced at various density feeding combinations at Social Security Pond and Rock Creek, 1984

5. Summarization of significant results of a three way analysis of variance comparing effects of different feeding rations (FR), densities (D), and pen locations (L) on final release weights of fed fish in pens (US--upstream; DS--downstream)

6. Mean weight of fed fish at various density-feeding combinations and in the hatchery, barrier net, and unfed pens during rearing trials at Social Security Pond and Rock Creek, 1984

7. Gill Na+, K+ - ATPase activity $(\bullet---\bullet)$ and lipid content $(\bullet---\bullet)$ for Spring Creek Hatchery fish, fed fish at Rock Creek and Social Security Pond and unfed fish in the barrier net ( 0 ) and pens ( $\square$ ) at Rock Creek during rearing trials, 1984

8. Summarization of selected criteria for future releases compared with observed growth, water temperatures and smoltification activity for fish held at high density at Social Security Pond and Rock Creek, 1984 


\section{LIST OF TABLES}

Table

Page

1. Water quality measurements at Rock Creek and Social Security Pond, 1984

2. Densities (No./m3) of microcrustacean zooplankton at Social Security Pond and Rock Creek at beginning, middle, and end of pen-rearing trials

3. Densities (No./m3) of Daphnia, Cyclopoida, and Bosmina found in backwaters and embayments in 1982, 1987-, and 1984 (sample dates in parentheses)

4. Number of fish stocked, mortality, and number of fish released (total number,number/lb., and number/ft 3 of water in enclosure) and condition factor at Social Security Pond which were reared in pens at high and low densities at full and 3/4 of regular hatchery ration, 1984

5. Number of fish stocked, mortality, number of fish released (total number, number/lb., and number/ft3 of water in enclosure), and condition factor at Rock Creek which were reared in pens at high and low density at full and 3/4 of regular hatchery ration, 1984

6. Multiple comparison (Newman-Keuls test) of significant differences in instantaneous growth at Social Security Pond and Rock Creek by time (two-week periods). Continuously underlined values are not significantly different at 0.05 level

7. Food conversion rate (wt food fed/wt gain) at Social Security Pond and Rock Creek for fish reared at high and low densities and fed full and 3/4 hatchery rations, 1984

8. Numbers and pounds of fish stocked, mortality, numbers and pounds of fish released, length-weight gain, and condition factor $(\mathrm{k})$ of unfed fish reared in a barrier net and pens at Rock Creek, 1984

9. Predators ( $>200 \mathrm{~mm}$ ) collected from barrier net in Rock Creek, 1984 


\section{LIST OF TABLES CONTINUED}

Table

Page

10. Gill ATPase Na+-K+ concentrations and instantaneous growth rates of unfed fish in net-pens and in the barrier net at Rock Creek, 1984.

11. Loading densities used, or recommended for culturing salmonids in net-pen enclosures (pounds/ft 3 in parentheses) 


\begin{abstract}
Backwaters and ponds along the Columbia River upstream of production hatcheries may provide opportunities for creating low cost rearing facilities and additional space to accommodate hatchery-thinning releases. Upriver bright, age-0 fall Chinook salmon (Dnchorynchus

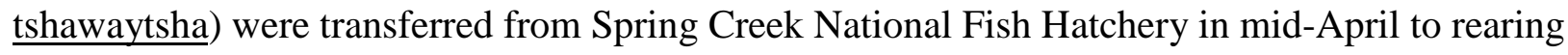
sites located 62 and 125 miles upstream from the hatchery and reared in netted enclosures for 6-8 weeks prior to release.
\end{abstract}

All fish reared at the off-station sites displayed increased growth rates and accelerated smoltification rates when compared to fish held in the hatchery. Highest growth rates were for fish reared in net pens at low densities and full feeding rations but more fish per unit volume were obtained when reared at higher density and a full feeding ration. Increased mortalities were associated with an outbreak of enteric redmouth disease (Yersinia ruckeri) when temperature exceeded $16 \mathrm{C}$, especially for fish reared at high density.

Density of unfed fish stocked in a barrier net and net pens was low in relation to those of fed fish, but the natural food available was adequate for growth in excess of that observed in the hatchery. Mortality was relatively high (30\%) in the barrier net, less than $1 \%$ for unfed fish in pens, and ranged from about $1 \%$ to $16 \%$ for fed fish in pens. 


\section{INTRODUCTION}

Anadromous salmonid fish runs in the Columbia River could be improved if returning adults migrated farther upstream in the river rather than returning to hatcheries of origin located on the lower Columbia River. In 1983, a study intended to enhance survival and return of upriver bright fall chinook salmon (Onchorynchus tshawaytsha) to upstream locations was initiated by the U.S. Fish and Wildlife Service. The goal of the study was to evaluate rearing and imprinting fall chinook salmon smolts in net pens located in the mid-Columbia Basin. A backwater (Rock Creek, river km 367) and a pond adjoining the river (Social Security Pond, river km 468) were selected as study sites (Novotny et al. 1984). If the present studies prove successful, the rearing methods developed may be used at other locations throughout the system to rear and imprint fall chinook salmon as well as other selected anadromous species.

Rearing trials in 1984 were primarily concerned with determining acceptable holding densities and feeding rations, while monitoring growth, survival, disease, and rearing methods. Data obtained during these trials will be used to establish stocking densities and feeding rations for the next three years of the study. Capture of adults from these release groups will be required to fully evaluate the success of off-station rearing, imprinting and release. Rearing costs and adult captures will be used to compare the cost/benefit of these methods with more traditional hatchery procedures. 


\section{METHODS}

Water temperatures, dissolved oxygen concentrations, and Secchi disk measurements were recorded at each location starting one week prior to stocking and continuing until release of all fish; conductivity and $\mathrm{pH}$ were recorded intermittently during the study period. Twenty-two additional water quality parameters were analyzed (Appendices $1 \& 2$ ) by a certified laboratory (Lauck's Testing Laboratories, Inc., Seattle) at the beginning, mid-point, and end of the rearing period. Zooplankton samples were taken at those times using a towed (from bottom to surface) Miller sampler.

The juvenile fall chinook salmon used in the study were progeny of bright fall chinook salmon adults taken from the Bonneville Dam fish ladder and spawned by the Oregon Department of Fish and Wildlife. The fish were initially incubated and reared at Spring Creek National Fish Hatchery (SCNFH). Fish were transferred from SCNFH to Social Security Pond (SSP) and Rock Creek (RC) on April 18 and 19, 1984, respectively.

Fish were placed in net-pens $(6.1 \mathrm{~m} \times 6.1 \mathrm{~m} \times 2.1 \mathrm{~m} ; 4.8 \mathrm{~mm}$ mesh) at high $(\approx z z 430 \mathrm{~g} / \mathrm{m} 3)$ and low $(\approx 210 \mathrm{~g} / \mathrm{m} 3)$ densities and were fed at full (3-4\% body weight) and 3/4 full hatchery rations using Abernathy Dry Diet (prior to transfer, in SCNFH, the fish were fed a ration of Biodiet ${ }^{\mathrm{a}}$ grower granules). Numbers of fish stocked at high density were based on minimal flows, suitable water quality, maximum water temperatures of $16 \mathrm{C}$, release weights of 20 fish $/ \mathrm{kg}$ (45 fish/lb), and using hatchery carrying capacity estimates calculated by Leitritz and Lewis (1976) (Appendix 3).

A representative sample of fish was weighed and counted during each transfer in order to adjust densities in pens as nearly as possible to predetermined numbers (based on numbers of fish/kg). Reassessment of original stocking densities after a few days indicated that the number of fish stocked at SSP in pen \#8 (low density, 3/4 ration) was lower than intended. Fish were subsequently redistributed among the pens to conform to the original study design.

a. Reference to trade names does not imply endorsement by the Federal Government. 
The daily ration was calculated from temperatures and projected and measured growth rates (Denel et al. 1942; Piper et al. 1982); feeding rates were adjusted bi-weekly. Food was dispensed with automatic feeders from 5-12 times throughout the daylight hours during the study. Two pens (replicates) of fish at each density/feeding combination were reared at each location.

Growth rates of fed fish were calculated every two weeks throughout the study using fork lengths and weights from a sample of 25-50 fish from each of the pens and from the same stock of fish held in the hatchery. Fish were crowded into one end of the net pen and then collected by dip-net. Instantaneous growth rates $\left(\mathrm{IGR}=\log _{\mathrm{e}} \mathrm{W}_{2}-\log _{\mathrm{e}} \mathrm{W}_{1} / \mathrm{T}\right)$ were calculated for comparison of relative growth rates among two-week periods. Significant differences among time periods were ranked using a Newman-Keuls multiple comparison test.

Mean fish weights among the various density-feeding treatments at release were analyzed using a three-way analysis of variance observations/cell) to determine if observed differences in size and pounds of fish produced were significant. Feeding ration (3/4 or full), density (high or low), and pen location (upstream side or downstream side- - i.e. upstream being nearer the water source) were factors tested. Because of the logistical layout of the pens, there was some question whether or not there were exact replicates due to water currents, food drift, etc. Therefore, for comparison of growth among treatments, pen location became a factor. A planned comparison (Sokal and Rohlf 1981) was used to compare growth of fed fish with that of the hatchery stock.

At RC fish were also placed within a barrier net (0.24 surface ha with $4 \mathrm{~m}$ mean depth and $8 \mathrm{~m}$ maximum depth; volume $9,278 \mathrm{~m}^{3}$ at minimum pool) and in two additional "predator exclusion" net pens (same dimensions and mesh size as net pens described above); none of these fish were fed. Installation problems delayed stocking of the barrier net and predator exclusion pens until May 15. A Newman-Keuls multiple comparison was used to compare growth among unfed fish in the barrier net and pens with growth in the hatchery.

Numbers of fish stocked were based on estimated food available to individual fish/day, calculated from data on similar backwater areas in the mid-Columbia Basin (Appendix 4) (personal communication, D. Rondorf, U.S. Fish and Wildlife Service, Cook, WA). Zooplankton and terrestrial drift, the primary components in juvenile salmon diet (Rondorf et al., 
in preparation), and to a lesser degree, benthos, were used to obtain a theoretical number of grams of food available for consumption/day (Appendix 4). Estimates of food required for maintenance of body weight at temperatures observed in RC were about $1.5 \%$ of body weight/day (Bardach et al. 1972). Based on these calculations it was determined that, without feeding, 73,250 fish could be reared in the barrier net and about 400 fish could be reared in each of the pens (Appendix 5). Actual numbers stocked were somewhat higher to compensate for anticipated mortality -- 79,450 in the barrier net and 550 and 500 in the pens.

Fish in the barrier net and predator exclusion pens were totally dependent on the natural food supply since they were not fed at any time during the study. Barrier net fish were exposed to predators (birds, fish, and mammals) while those in pens were protected from predation.

Length and weight samples of fish in the barrier net and predator exclusion pens were obtained after three weeks and at the conclusion of the study; samples were collected from the barrier net using a 30.3-meter (100 ft) seine.

Mortality in all enclosures were monitored daily; dead fish in net pens were removed and counted every other week unless numbers of carcasses increased substantially, requiring counting and removal weekly. A two-way analysis of variance with a Newman-Keuls multiple comparison test of the results was used to compare mortalities among fed fish at the various treatments. For the fish reared in the barrier net, the Chapman version of a Peterson population estimate (Ricker, 1975) was used to estimate the number of survivors at release (Appendix 6).

A complete health profile (Appendix 7) was conducted by the Lower Columbia River Health Center, U.S. Fish and Wildlife Service. Fish were sampled from each of the pens after four weeks of rearing and at release. Fish were treated for disease after an outbreak of Enteric Redmouth disease (Yersinia ruckeri) using TM-50 medicated (3-4 g teramycin/45 kg fish) Abernathy Dry Diet.

Ten fish from RC, SS P, and the hatchery were collected to determine gill ATPase levels during the fifth, sixth, seventh, and eighth weeks of rearing. Analyses were conducted by the National Marine Fisheries Service Aquaculture Field Station, Cook, Washington, using methods developed by Zaugg (1982). 
Fed fish were held for nearly eight weeks prior to release on June 12 at RC and June 13 at SSP. Unfed fish in the barrier net and pens at RC were released after six weeks, on June 26; all fish were released after dark.

A complete, chronological schedule of events for the 1984 brood year is included in Appendix 8 . 


\section{RESULTS}

\section{Water Quality}

Surface temperatures during the study ranged from $8.1 \mathrm{C}$ to $21.5 \mathrm{C}(7 \mathrm{C}-14.1 \mathrm{C})$ at $\mathrm{RC}$ and from 11.0 C to $18.7 \mathrm{C}(\mathrm{X}-15.0 \mathrm{C})$ at SSP (Table 1$)$. Temperatures were usually about $2^{\circ}$ lower near bottom than at the surface. Dissolved oxygen concentrations at the surface never dropped below $9.0 \mathrm{mg} / 1$ at either location, and concentrations near the bottom, while 2-3 mg/1 lower, were never observed below $6.0 \mathrm{mg} / 1$. Hydrogen ion concentration averaged 7.6 and 8.0 at $\mathrm{RC}$ and SSP, respectively. Mean conductivity readings were somewhat higher at SSP than at RC (197 umhos/cm vs. 178 umhos/cm) while Secchi disk transparencies were consistently higher at RC ranging between $1.2 \mathrm{~m}$ and $2.5 \mathrm{~m}$ at $\mathrm{RC}$ and between $0.7 \mathrm{~m}$ and $1.4 \mathrm{~m}$ at SSP. Other water quality parameters measured (Appendices $1 \& 2$ ) were within normal limits on a sustained basis and similar to levels recorded from the same areas in 1983 (U.S. Environmental Protection Agency 1976, Novotny et al. 1984).

\section{Zooplankton Abundance}

Daphnia, Cyclopoida, and Bosmina were the most abundant zooplankton taxa collected from both study areas (Table 2). At SSP two additional taxa were also relatively common, $\underline{\text { Chydorus }}$ in May and Calanoida in June. A total of eleven taxa were collected at SSP while seven taxa

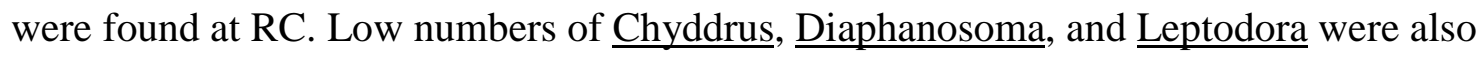
collected at RC, none in high abundance. Densities of zooplankton were relatively high during all sample periods at SS P, especially the Daphnia and Cyclopoida; peak numbers occurred in May. At RC, densities were relatively low in April, but increased in May and June. Peak numbers of Cyclopoida and Bosmina were collected in May, with Daphnia densities highest in June.

Densities of the three most abundant taxa in both areas were substantially higher than observed in samples collected during June in the main stem of the Columbia River in McNary Reservoir (Table 3) (Rondorf et al. in review). However, sample densities were more similar to those collected in August 1983, during the survey of backwater and acclimation ponds (Novotny et al. 1984). Densities of zooplankton in areas less influenced by water exchange, including backwaters and embayments have higher numbers of zooplankton available for fish food than areas more subject to higher water exchange rates. 
Table 1. Water quality measurements at Rock Creek and Social Security Pond, 1984.

Social

Security Pond

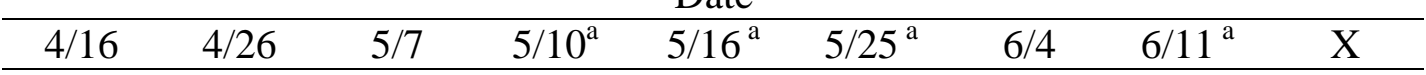

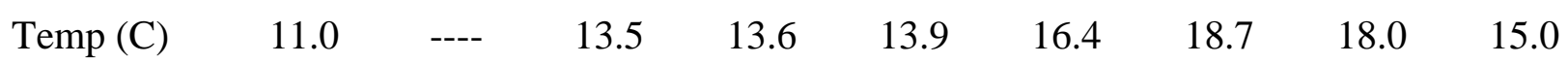

$\begin{array}{llllllllll}\text { Surface } & 8.0 & ---- & 12.3 & 12.3 & 12.8 & 14.6 & 16.7 & 16.1 & 13.2\end{array}$

Bottom

D.O. $(\mathrm{mg} / 1)$

$\begin{array}{llllllllll}\text { Surface } & 14.2 & ---- & 11.7 & 11.3 & 11.1 & 9.8 & 9.0 & 9.7 & 11.0\end{array}$

$\begin{array}{llllllllll}\text { Bottom } & 10.5 & ---- & 10.0 & 9.4 & 6.6 & 6.1 & 7.4 & 7.5 & 8.2\end{array}$

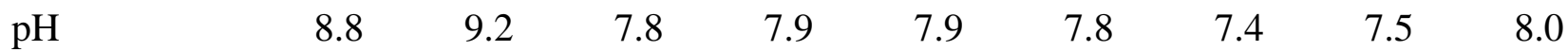

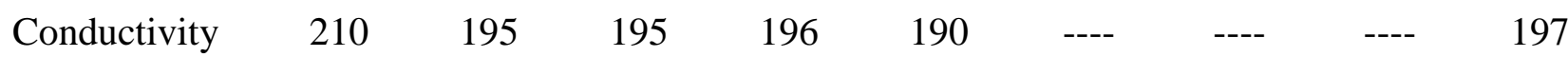

( $\left.{ }^{\mathrm{u}} \mathrm{mhos} / \mathrm{cm}\right)$

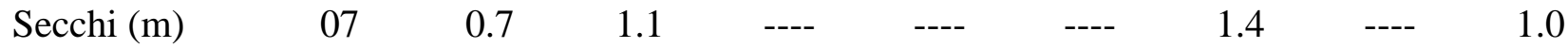

Rock Creek

Date

\begin{tabular}{lllllllllll}
\hline $4 / 17$ & $4 / 23$ & $5 / 7$ & $5 / 11 \mathrm{a}$ & $5 / 18$ & $5 / 25$ & $6 / 5$ & $6 / 11$ & $6 / 20$ & $6 / 26$ & $\mathrm{X}$ \\
\hline
\end{tabular}

Temp (C)

$\begin{array}{llllll}8.1 & 8.5 & 13.9 & 13.6 & 15.4 & 14.8\end{array}$

$\begin{array}{lllll}15.9 & 17.6 & 18.7 & 21.5 & 14.8\end{array}$

Surface

Bottom

$5.9 \quad--\quad 11.5 \quad 11.3$

$12.3 \quad 12$.

$15.2 \quad--$

15.

$18.3 \quad 12.8$

D.O. $(\mathrm{mg} / 1)$

Surface

$11.6 \quad---\quad 10.9 \quad 10.6$

$10.2 \quad 10.3$

0.39 .0

9.0

$--$

$\begin{array}{lll}10.2 & 9.1 & 10.2\end{array}$

Bottom

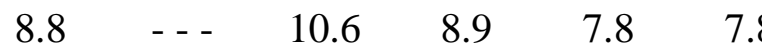

$8.2 \quad--$

$6.3 \quad 8.6$

8.4

$\mathrm{pH}$

$\begin{array}{lll}8.6 & 8.5 \quad 6.9\end{array}$

6.9

$\begin{array}{ll}7.5 & 7.3\end{array}$

7.4

6.9

7.6

Conductivity

$150 \quad 150$

$179 \quad 184$

193

192

201

178

("mhos/cm)

Secchi (m)

$1.2 \quad 1.4 \quad 1$.

1.9

$-$

$1.3 \quad \ldots$

2.2

2.5

1.8

a Dissolved oxygen taken prior to sunrise. 
Table 2. Densities $\left(\mathrm{No} . / \mathrm{m}^{3}\right)$ of microcrustacean zooplankton at Social Security Pond and Rock Creek at beginning, middle, and end of pen-rearing trials.

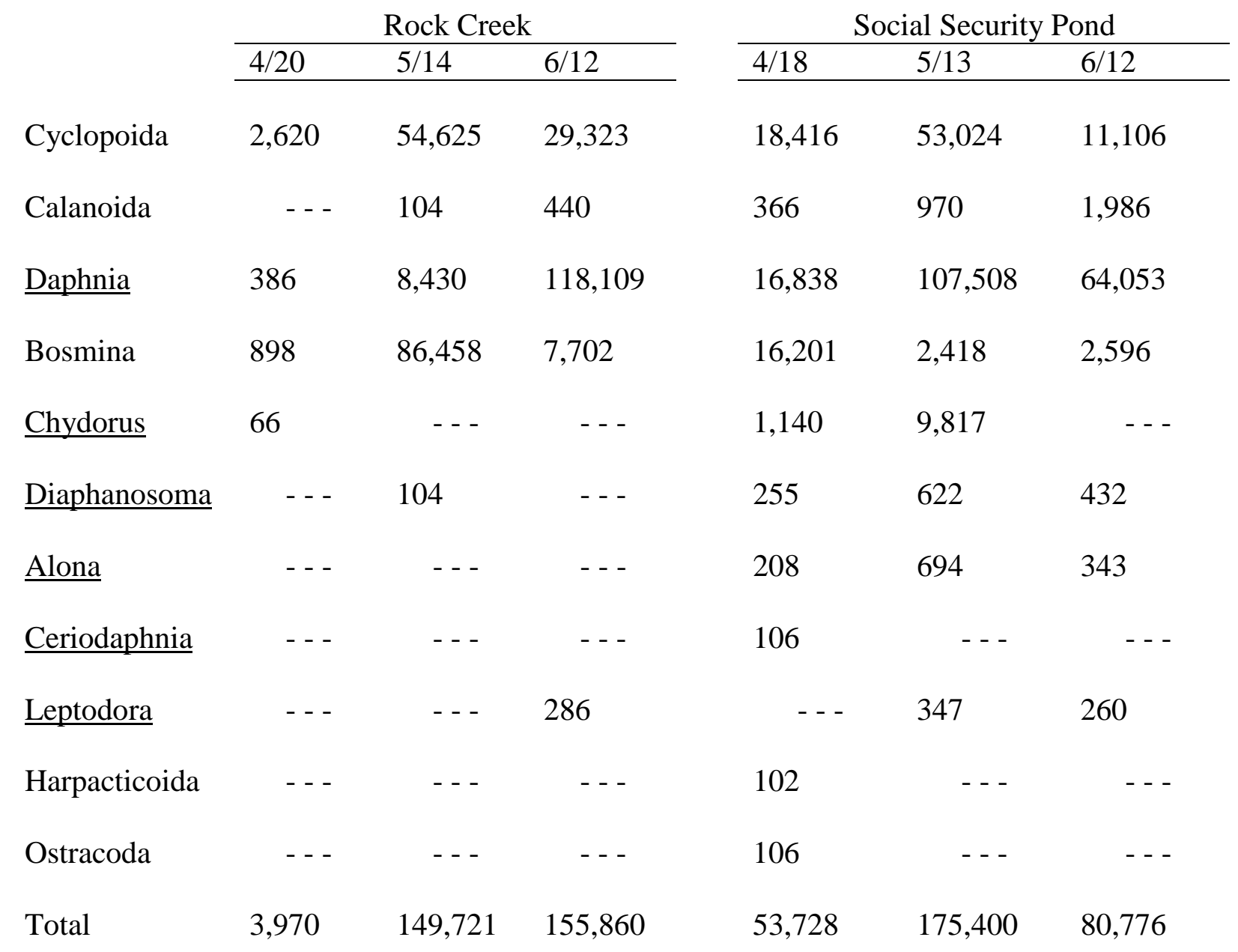




\section{$\underline{\text { Rearing of Fed Fish in Pens }}$}

Densities - Numbers of fish stocked in pens at high density averaged about 17,350 fish/pen (434 $\left.\mathrm{g} / \mathrm{m}^{3}\right)$, ranging from $17,106\left(424 \mathrm{~g} / \mathrm{m}^{3}\right)$ to $17,494\left(445 \mathrm{~g} / \mathrm{m}^{3}\right)$ (Tables 4 and 5). Pens stocked at low density (excluding Pen 8 at SSP which was stocked somewhat lighter than other low-density pens - - see methods) contained an average of $8300 \mathrm{fish} /$ pen $\left(210 \mathrm{~g} / \mathrm{m}^{3}\right)$, ranging from 8197 (207 $\left.\mathrm{g} / \mathrm{m}^{3}\right)$ to $8425\left(212 \mathrm{~g} / \mathrm{m}^{3}\right)$. High rearing density was based on low rates of water exchange and anticipated high mortality -- a "worst case" scenario. At high rearing density 17,000-17,500 fish/pen were required at stocking to obtain a relatively conservative estimate of 12,750 fish/pen $\left(0.1 \mathrm{lbs} / \mathrm{ft}^{3}\right.$, or $\left.1.59 \mathrm{~kg} / \mathrm{m}^{3}\right)$ at release (Appendix 3). However, actual flows through the pens were higher and mortalities lower than projected resulting in survival and release of 14,00017,000 fish/pen from high-density treatments. Numbers of fish released from pens stocked at low density averaged about 7,600 fish/pen, ranging from 5,876 to 8,223 fish/pen.

High-density treatments were much below maximum loading densities recommended for hatchery ponds (Wedemeyer et al. 1981), especially in a single pass water system. Loading density at SSP was 0.22 lbs. of fish.gal-1.min-1.inch-1 (0.0012 kg.1- $\left.{ }^{1} . \mathrm{min}^{-}{ }^{1} . \mathrm{mm}^{-}{ }^{1}\right)$ and at RC

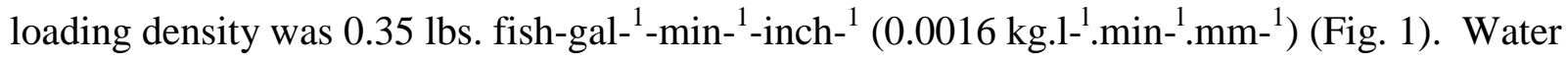
movement in SSP and RC was probably more complicated than simply a unidirectional flow such as occurs in a hatchery, but for the estimate of water exchange through the net pens, movement was considered single pass (Appendices $9 \& 10$ ). Using these criteria high-density pens at SSP and RC may have been stocked $25-35 \%$ of the maximum, assuming water temperatures and water quality would have been maintained throughout the study. At SCNFH, a recirculating system, maximum loading densities at the temperatures $(10.0 \mathrm{C})$ maintained in the hatchery would be about $0.80 \mathrm{lbs}$ of fish.gal- ${ }^{1} \cdot \mathrm{min}^{-1} \cdot \mathrm{mm}^{-1}\left(0.0039 \mathrm{~kg} \cdot{ }^{-}{ }^{1} \cdot \mathrm{min}^{-}{ }^{1} . \mathrm{mm}^{-}{ }^{1}\right)$ according to hatchery densities recommended by Wedemeyer et al. (1981). These maximum recommended hatchery densities were 2-3 times higher than in the high-density pens.

Mortality - Highest average mortalities over the eight week period occurred among fish reared at high density at SSP (13.8\%), while mortalities of fish reared at low density at that site averaged 7.1\% (Table 4). Mortalities at RC were less at high and low rearing densities, averaging $4.8 \%$ and $1.4 \%$, respectively (Table 5). 
Table 3. Densities (No./m ${ }^{3}$ of Daphnia, Cyclopoida, and Bosmina found in backwaters and embayments in 1982,1983, and sample dates in parentheses).

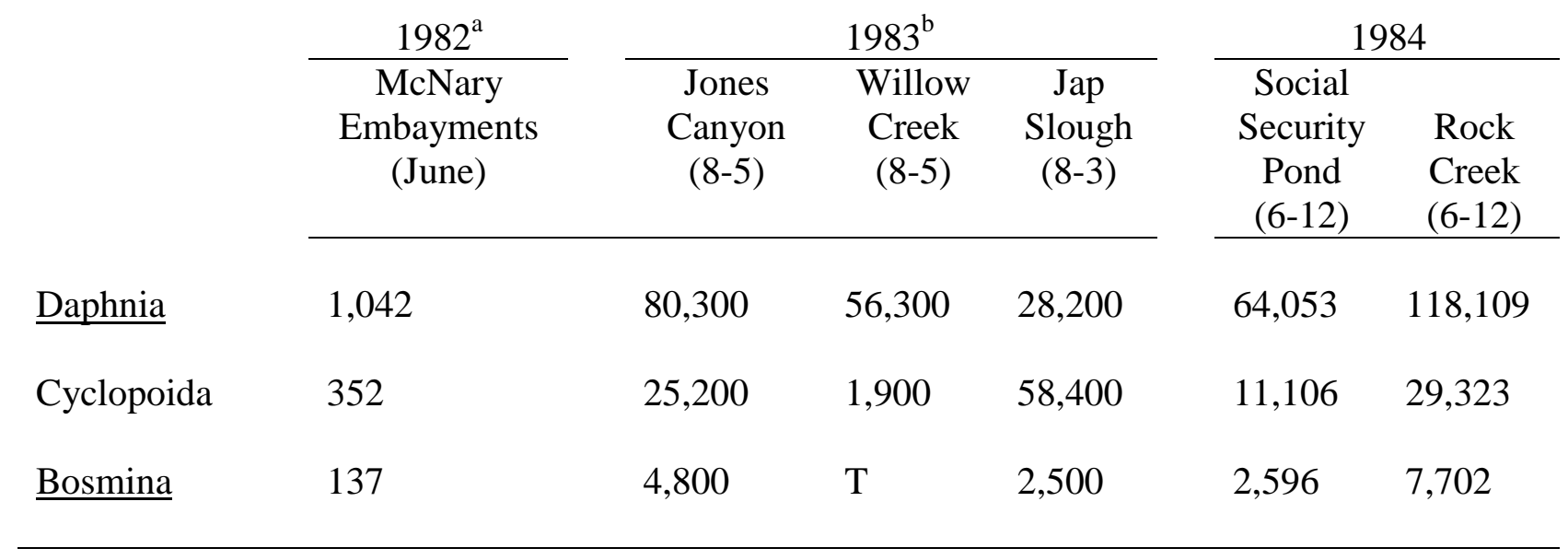

a Rondorf et al. in review

b Novotny et al. 1984 
Table 4. Number of fish stocked, mortality, and number of fish released (total number, number/lb., and number/ft ${ }^{3}$ of water in enclosure) and condition factor at Social Security Pond which were reared in pens at high and low densities at full and 3/4 of regular hatchery ration, 1984.

\begin{tabular}{|c|c|c|c|c|c|c|c|c|}
\hline \multirow[b]{2}{*}{ Characteristic } & \multicolumn{2}{|c|}{ High density-full } & \multicolumn{2}{|c|}{ High density-full-3/4 } & \multicolumn{2}{|c|}{ Low density-full } & \multicolumn{2}{|c|}{ Low density-full-3/4 } \\
\hline & 1 & 2 & 3 & 4 & 5 & 6 & 7 & 8 \\
\hline No. fish stocked & 17,237 & 17,261 & 17,106 & 17,330 & 8,425 & 8,197 & 8,215 & $6,567^{\mathrm{a}}$ \\
\hline $\begin{array}{l}\text { Natural mortality } \\
\%\end{array}$ & $\begin{array}{l}1,839 \\
(10.7)\end{array}$ & $\begin{array}{l}2,678 \\
(15.5)\end{array}$ & $\begin{array}{l}2,801 \\
(16.4)\end{array}$ & $\begin{array}{l}2,179 \\
(12.6)\end{array}$ & $\begin{array}{c}574 \\
(6.8)\end{array}$ & $\begin{array}{c}484 \\
(5.9)\end{array}$ & $\begin{array}{l}643 \\
(7.8)\end{array}$ & $\begin{array}{l}525 \\
(8.0)\end{array}$ \\
\hline $\begin{array}{l}\text { Sample mortality } \\
\%\end{array}$ & $\begin{array}{c}168 \\
(1.0)\end{array}$ & $\begin{array}{l}160 \\
(0.9)\end{array}$ & $\begin{array}{c}165 \\
(1.0)\end{array}$ & $\begin{array}{l}174 \\
(1.0)\end{array}$ & $\begin{array}{l}169 \\
(2.0)\end{array}$ & $\begin{array}{l}171 \\
(2.1)\end{array}$ & $\begin{array}{l}182 \\
(2.2)\end{array}$ & $\begin{array}{l}166 \\
(2.5)\end{array}$ \\
\hline Total no. released & 15,230 & 14,423 & 14,140 & 14,977 & 7,682 & 7,542 & 7,390 & 5,876 \\
\hline $\begin{array}{l}\text { Total lb stocked } / \mathrm{ft}^{3} \\
\left(\mathrm{~g} / \mathrm{m}^{3}\right)\end{array}$ & $\begin{array}{c}.026 \\
(421)\end{array}$ & $\begin{array}{l}.026 \\
(421)\end{array}$ & $\begin{array}{c}.026 \\
(421)\end{array}$ & $\begin{array}{c}.027 \\
(438)\end{array}$ & $\begin{array}{l}.013 \\
(211)\end{array}$ & $\begin{array}{l}.013 \\
(211)\end{array}$ & $\begin{array}{l}.013 \\
(211)\end{array}$ & $\begin{array}{l}.010 \\
(163)\end{array}$ \\
\hline $\begin{array}{l}\text { Total } \mathrm{lb} \text { released } / \mathrm{ft}^{3} \\
\left(\mathrm{~g} / \mathrm{m}^{3}\right)\end{array}$ & $\begin{array}{c}.076 \\
(1232)\end{array}$ & $\begin{array}{c}.072 \\
(1167)\end{array}$ & $\begin{array}{c}.060 \\
(973)\end{array}$ & $\begin{array}{c}.066 \\
(1070)\end{array}$ & $\begin{array}{l}.039 \\
(632)\end{array}$ & $\begin{array}{l}.038 \\
(616)\end{array}$ & $\begin{array}{r}.032 \\
(519)\end{array}$ & $\begin{array}{r}.030 \\
(486)\end{array}$ \\
\hline Net gain $(\%)$ & 65.2 & 63.1 & 56.2 & 59.9 & 67.1 & 67.3 & 61.2 & 66.6 \\
\hline $\begin{array}{l}\text { No. fish } / \mathrm{lb} \text { released } \\
(\text { No. fish } / \mathrm{kg})\end{array}$ & $\begin{array}{c}71.6 \\
(158)\end{array}$ & $\begin{array}{l}69.0 \\
(152)\end{array}$ & $\begin{array}{c}75.0 \\
(165)\end{array}$ & $\begin{array}{c}73.9 \\
(163)\end{array}$ & $\begin{array}{c}64.1 \\
(141)\end{array}$ & $\begin{array}{c}67.6 \\
(149)\end{array}$ & $\begin{array}{c}77.1 \\
(170)\end{array}$ & $\begin{array}{c}67.8 \\
(149)\end{array}$ \\
\hline Condition factor $(\mathrm{k})$ & 1.12 & 1.12 & 1.13 & 1.15 & 1.11 & 1.10 & 1.11 & 1.14 \\
\hline
\end{tabular}

a Initially stocked at lower density (2,53 fish in pen); density adjusted after 10 days to 6,567 
Table 5. Number of fish stocked, mortality, and number of fish released (total number, number/lb., and number/ft ${ }^{3}$ of water in enclosure) and condition factor at Rock Creek which were reared in pens at high and low densities at full and 3/4 of regular hatchery ration, 1984.

\begin{tabular}{|c|c|c|c|c|c|c|c|c|}
\hline \multirow[b]{2}{*}{ Characteristic } & \multicolumn{2}{|c|}{ High density-full } & \multicolumn{2}{|c|}{ High density-full-3/4 } & \multicolumn{2}{|c|}{ Low density-full } & \multicolumn{2}{|c|}{ Low density-full-3/4 } \\
\hline & 1 & 2 & 3 & 4 & 5 & 6 & 7 & 8 \\
\hline No. fish stocked & 17,248 & 17,494 & 17,405 & 17,7180 & 8,198 & 8,512 & 8,400 & 8,355 \\
\hline $\begin{array}{l}\text { Natural mortality } \\
\%\end{array}$ & $\begin{array}{l}991 \\
(5.7)\end{array}$ & $\begin{array}{l}1,016 \\
(5.8)\end{array}$ & $\begin{array}{c}897 \\
(5.2)\end{array}$ & $\begin{array}{l}452 \\
(2.6)\end{array}$ & $\begin{array}{c}61 \\
(0.7)\end{array}$ & $\begin{array}{c}101 \\
(1.2)\end{array}$ & $\begin{array}{l}156 \\
(1.9\end{array}$ & $\begin{array}{c}148 \\
(1.8)\end{array}$ \\
\hline $\begin{array}{l}\text { Sample mortality } \\
\%\end{array}$ & $\begin{array}{c}195 \\
(1.1)\end{array}$ & $\begin{array}{c}188 \\
(1.1)\end{array}$ & $\begin{array}{c}188 \\
(1.10)\end{array}$ & $\begin{array}{c}188 \\
(1.1)\end{array}$ & $\begin{array}{l}188 \\
(2.3)\end{array}$ & $\begin{array}{l}188 \\
(2.2)\end{array}$ & $\begin{array}{l}188 \\
(2.2)\end{array}$ & $\begin{array}{l}198 \\
(2.4)\end{array}$ \\
\hline Total no. released & 16,062 & 16,290 & 16,320 & 17,078 & 7,949 & 8,223 & 8,056 & 8,009 \\
\hline $\begin{array}{l}\text { Total lb stocked } / \mathrm{ft}^{3} \\
\left(\mathrm{~g} / \mathrm{m}^{3}\right)\end{array}$ & $\begin{array}{c}.028 \\
(4541)\end{array}$ & $\begin{array}{l}.028 \\
(454)\end{array}$ & $\begin{array}{l}.028 \\
(454)\end{array}$ & $\begin{array}{l}.028 \\
(454)\end{array}$ & $\begin{array}{l}.013 \\
(211)\end{array}$ & $\begin{array}{l}.014 \\
(227)\end{array}$ & $\begin{array}{l}.013 \\
(211)\end{array}$ & $\begin{array}{l}.013 \\
(211)\end{array}$ \\
\hline $\begin{array}{l}\text { Total } \mathrm{lb} \text { released } / \mathrm{ft}^{3} \\
\left(\mathrm{~g} / \mathrm{m}^{3}\right)\end{array}$ & $\begin{array}{c}.082 \\
(1330)\end{array}$ & $\begin{array}{c}.083 \\
(1346)\end{array}$ & $\begin{array}{c}.062 \\
(1005)\end{array}$ & $\begin{array}{l}.080 \\
(1297)\end{array}$ & $\begin{array}{l}.051 \\
(827)\end{array}$ & $\begin{array}{c}.047 \\
(7626)\end{array}$ & $\begin{array}{c}.042 \\
(681)\end{array}$ & $\begin{array}{l}.042 \\
(681)\end{array}$ \\
\hline Net gain $(\%)$ & 66.4 & 66.3 & 55.0 & 64.5 & 74.5 & 71.4 & 68.1 & 68.6 \\
\hline $\begin{array}{l}\text { No. fish } / \mathrm{lb} \text { released } \\
\text { (No. fish } / \mathrm{kg} \text { ) }\end{array}$ & $\begin{array}{c}64.0 \\
(140)\end{array}$ & $\begin{array}{l}57.5 \\
(127)\end{array}$ & $\begin{array}{c}77.2 \\
(170)\end{array}$ & $\begin{array}{l}74.5 \\
(164)\end{array}$ & $\begin{array}{l}47.7 \\
(105)\end{array}$ & $\begin{array}{l}51.9 \\
(114)\end{array}$ & $\begin{array}{c}62.9 \\
(139)\end{array}$ & $\begin{array}{c}61.0 \\
(134)\end{array}$ \\
\hline Condition factor $(\mathrm{k})$ & 1.12 & 1.15 & 1.12 & 1.175 & 1.19 & 1.17 & 1.201 & 1.17 \\
\hline
\end{tabular}




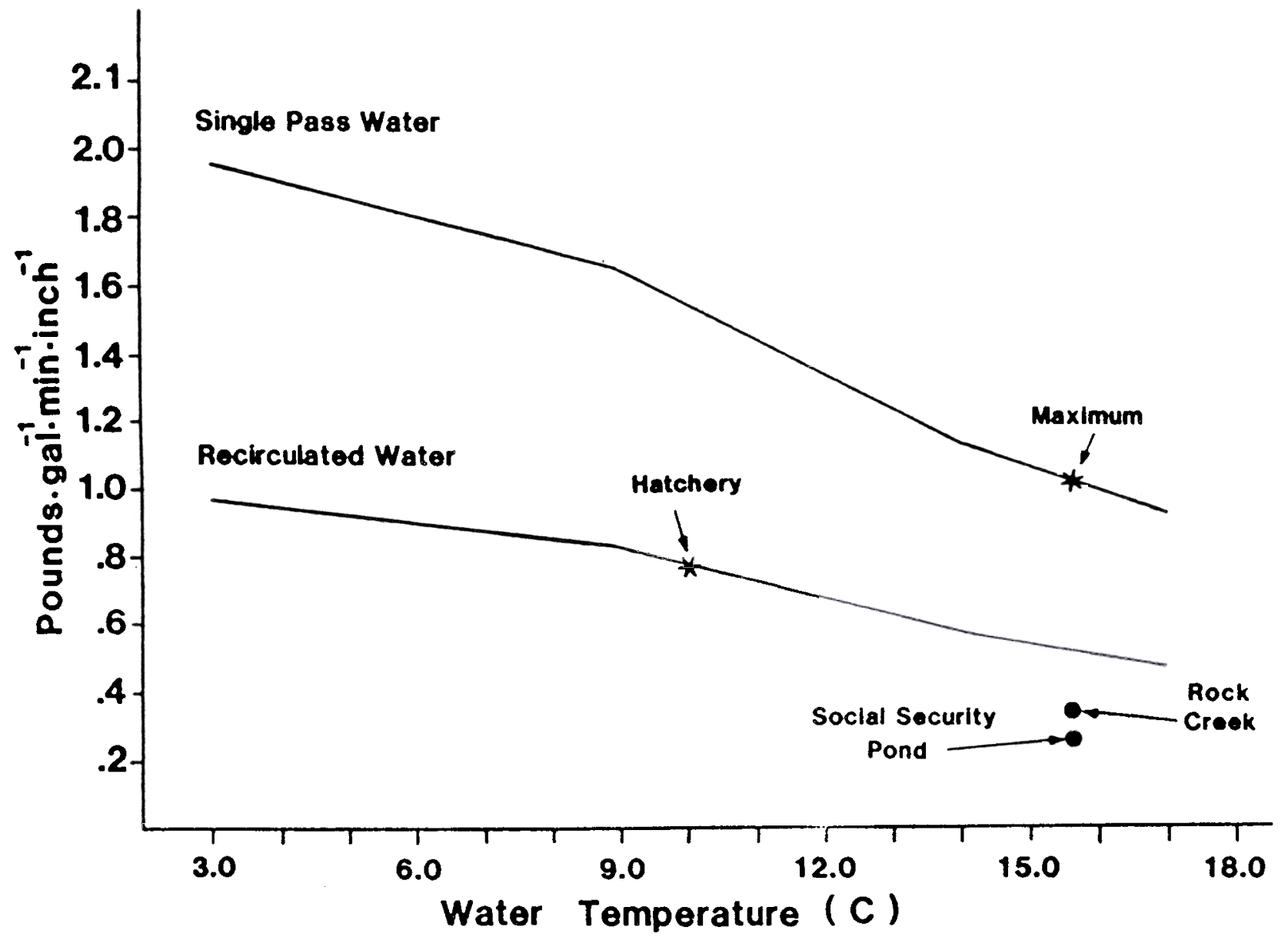

Figure 1. Recommended hatchery pond loading densities at various temperatures using single pass and recirculated water (Wedemeyer et al. 1981). Maximum recommmended loading densities for Spring Creek Hatchery and for off-station net pen enclosures and actual loading densities in high density pens at Rock Creek and Social Security Pond in 1984 are indicated. 


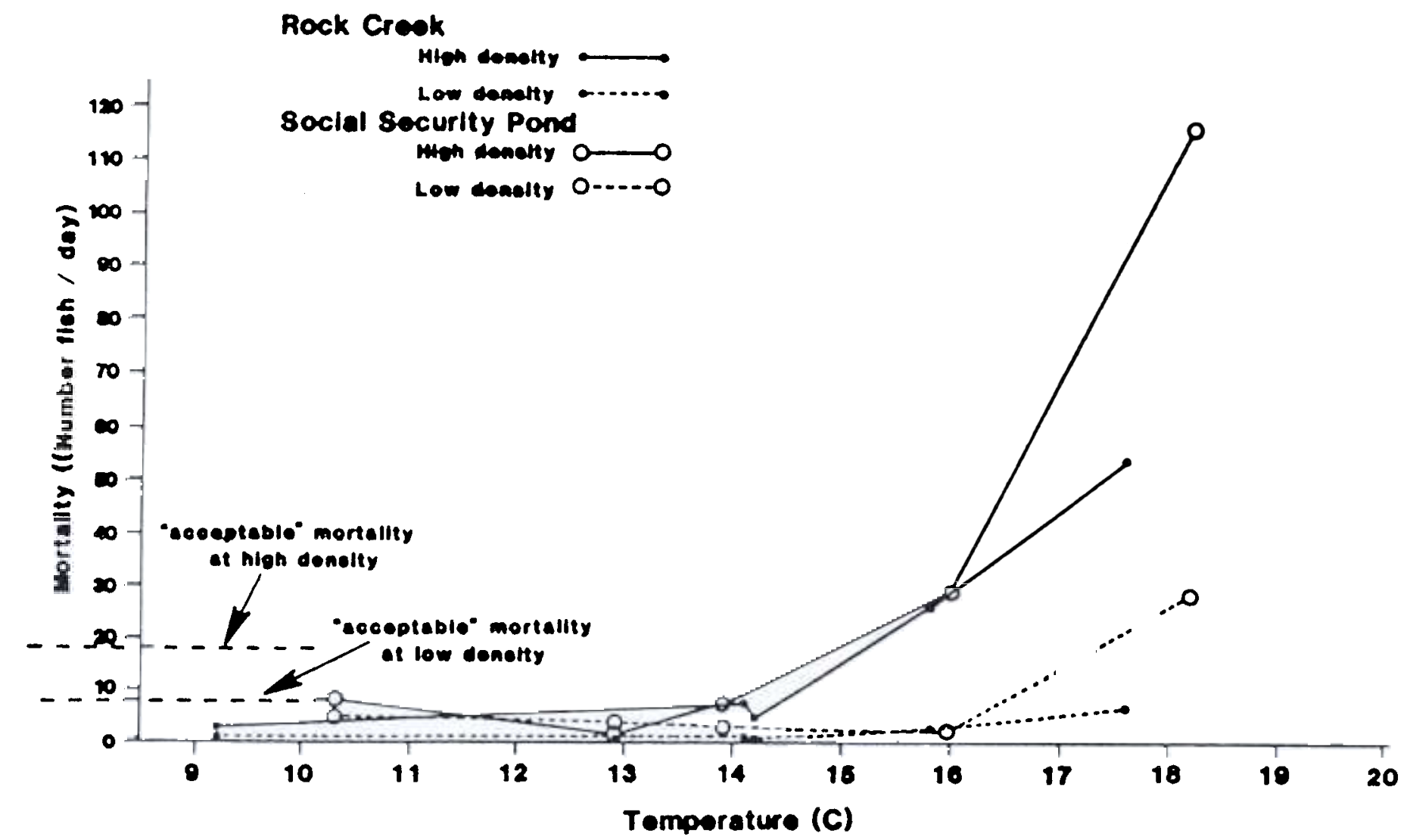

Figure 2. Mortality rates of fed fish at Social Security Pond and Rock Creek at temperatures encountered during 1984 rearing trials. 


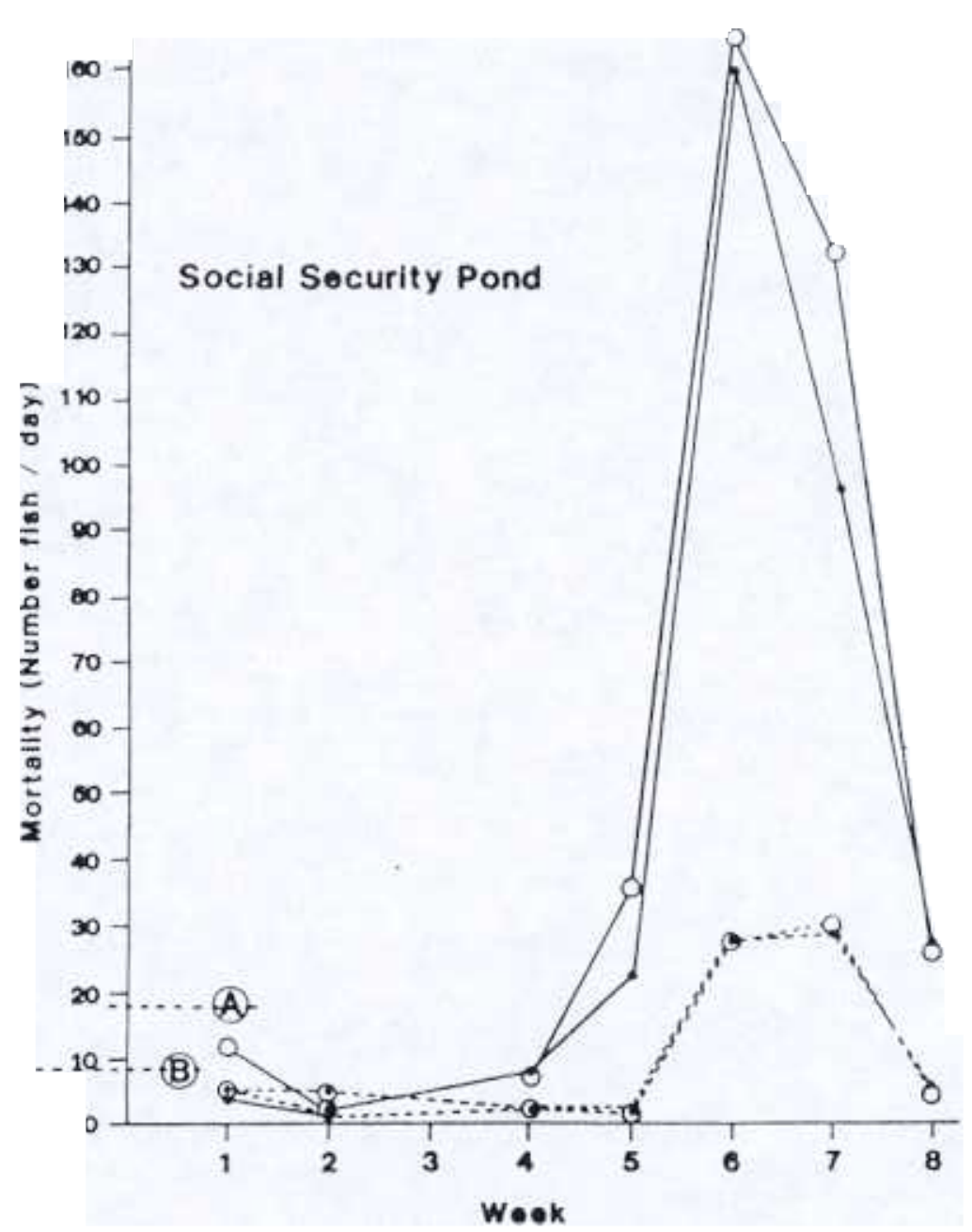

Migh denelly-tull retlon $\mathrm{O}-\mathrm{O}$

HIgh denelly-3/4 retlon

Low denelty-full ration

Low denelty-3/4 ration

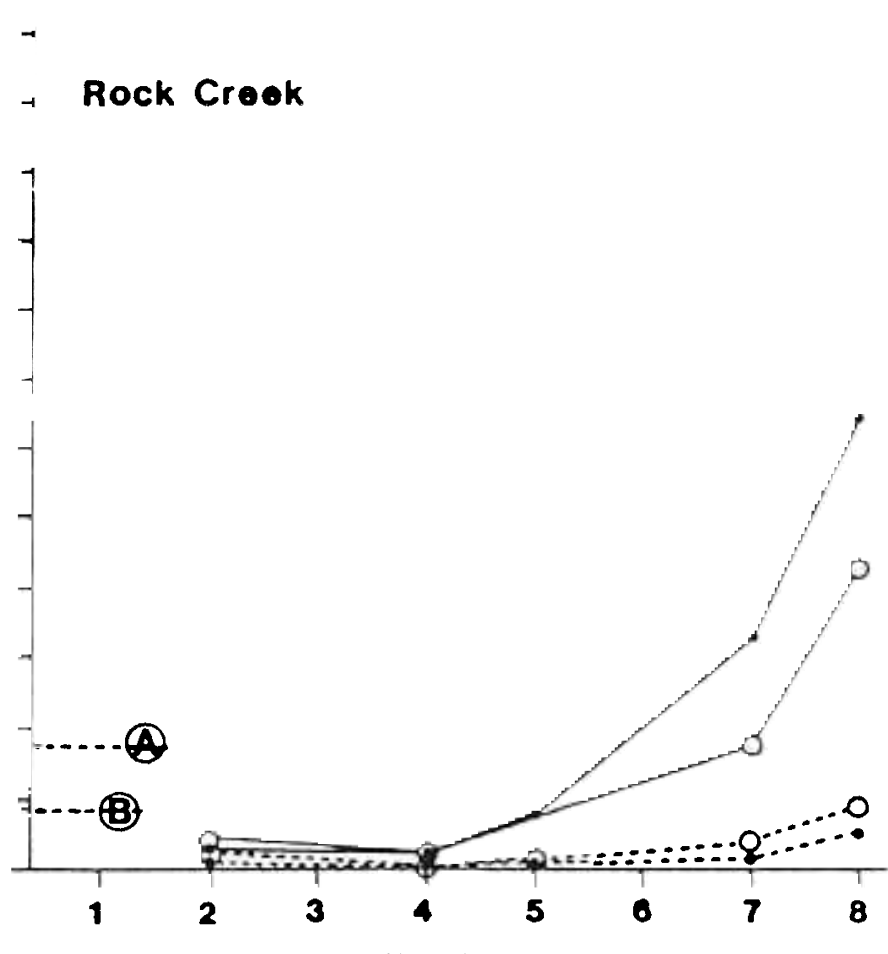

Figure 3. Weekly mortality rates of fed fish at Social Security Pond and Rock Creek, 1984. ( A -. "acceptable" mortality at high density; B --"acceptable" mortality at low density). 

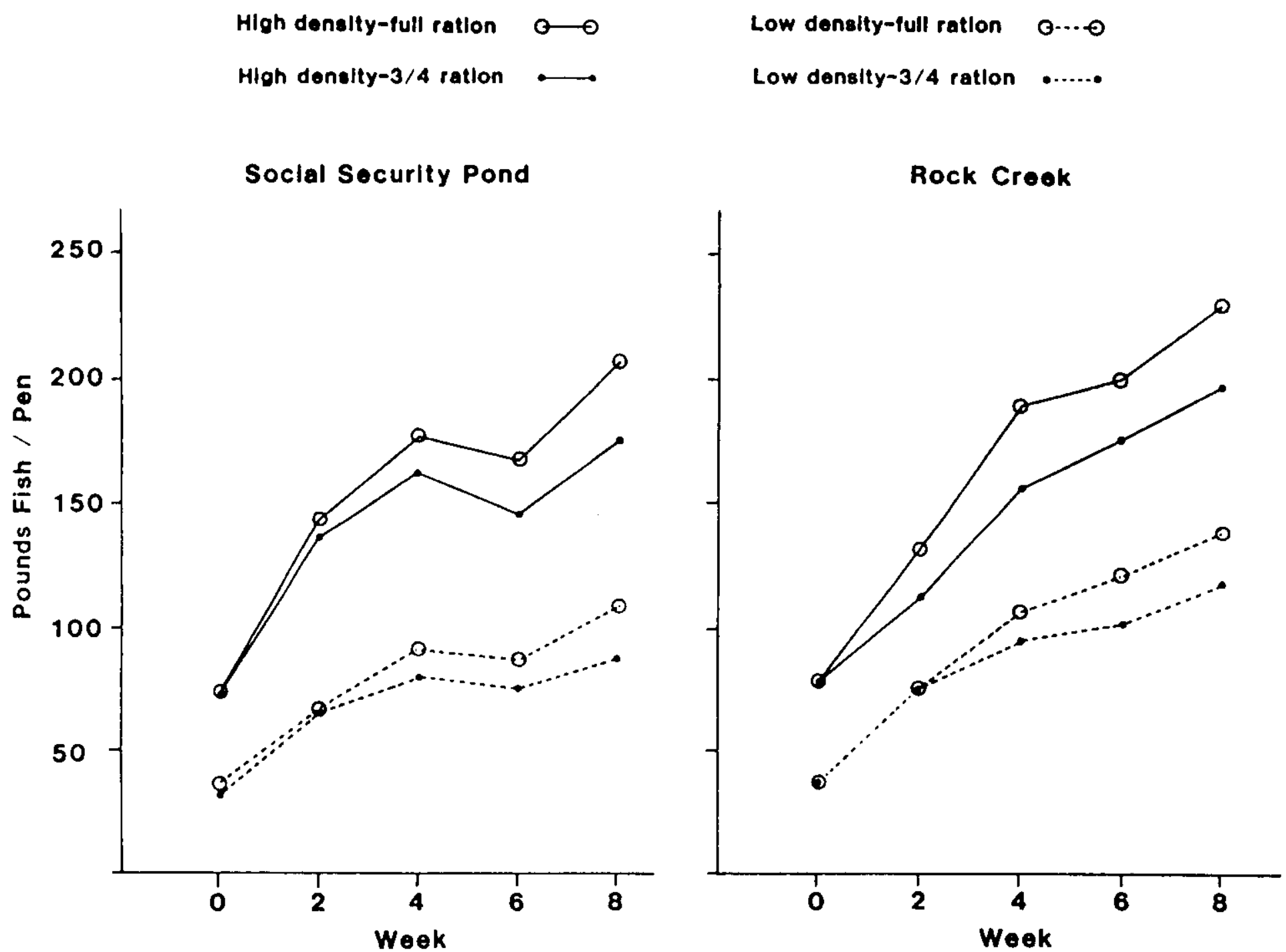

Figure 4. Total pounds of fish produced at various density feeding combinations at Social Security Pond and Rock Creek, 1984. 
Rates of mortality at both locations were significantly higher for fish reared at higher density than at lower density (analysis of variance; $\mathrm{P}<0.05$ ). Mortality at low density among fed fish at 3/4 and full ration was not significantly different in either area (Appendix 11).

At high density, mortality did not exceed levels commonly regarded as "acceptable" in hatchery production (0.10\%/day) (personal communication, S. Leek, Lower Columbia Fish Health Center, U.S. Fish and Wildlife Service, Cook, Washington) until water temperatures reached nearly 16 C (Figs. 2 and 3). Among fish reared at low density, mortality never exceeded "acceptable" limits at RC, even when water temperatures exceeded 17C. At about 16C SSP mortality increased for fish reared at low densities.

The presence of enteric redmouth disease (ERM) was confirmed at SSP on May 26 (Appendix 7), suggesting that the disease was probably the cause of the observed increase in mortality. Columnaris disease (Flexibacter columnaris) may have also been present, but was not confirmed during the routine disease check. The ERM disease was originally diagnosed in the hatchery stock at SCNFH prior to transfer to off-station sites (personal communication, S. Leek, Lower Columbia Fish Health Center). Neither the level of infection nor the mortality rate prior to May 26 indicated that ERM was a serious problem. After a 10-day treatment with medicated food (TM-50) mortality rates decreased and at release levels were similar to those observed prior to the outbreak (Fig. 3).

On May 15, fish reared at RC had also been tested positive for ERM, but rate of mortality was not epizootic. Upon confirmation of the outbreak at SSP, however, the RC fish were fed a TM50 medicated diet, prophylactically, for a two-week period, apparently retarding an ERM outbreak. Nevertheless, increased mortalities were noted in pens at RC toward the end of the eight-week period, especially for fish reared at high density. These mortalities were thought to be associated with confirmed incidence of columnaris disease rather than ERM.

Weight - Weight of fish stocked in pens at high density averaged $416 \mathrm{~g} / \mathrm{m}^{3}\left(0.026\right.$ pounds/ft $\left.{ }^{3}\right)$ and at low density averaged $208 \mathrm{~g} / \mathrm{m}^{3}\left(0.013\right.$ pounds/ $\left./ \mathrm{ft}^{3}\right)$ (Tables 4 and 5). Total weights of fish released from all density-feeding treatments after eight weeks of rearing were higher at RC than at SSP because of the higher mortalities which had occurred at SSP during the sixth and seventh weeks of rearing. In both areas total weight of fish released ranged from $1200 \mathrm{~g} / \mathrm{m}^{3}(0.074$ $\left.\mathrm{lbs} / \mathrm{ft}^{3}\right)$ to $503 \mathrm{~g} / \mathrm{m}^{3}\left(\mathrm{o} .031 \mathrm{lbs} / \mathrm{ft}^{3}\right)$. The highest poundage of fish was released from pens with 
high density and full ration treatments. Progressively less weight was released from pens with treatments of high density-3/4 ration, low density-full ration, and low density-3/4 ration (Fig. 4). Only slight differences were observed in condition factors among fish in either location (Tables 4 and 5).

Size of fish in all pens at release averaged about 156 fish $/ \mathrm{kg}$ (71 fish/lb) at SSP and 137/kg (62/lb) at RC (Tables 4 and 5). Largest fish reared at both locations were in low density-full ration pens -- 145/kg (66/lb) at SSP and 110/kg (50/lb) at RC -- while sizes in other pens ranged from $150-165 / \mathrm{kg}$ (68 to $75 / \mathrm{lb})$ at SSP and from $128-170 / \mathrm{kg}$ (58 to $77 / \mathrm{lb})$ at RC.

Although fish were significantly larger $(\mathrm{P}<0.05)$ in low density pens, the response of growth rates (as measured by mean fish weight) to different feeding rations was similar at both densities (Fig. 5, Appendix 12). However, fish in downstream pens at 3/4 ration at both SSP and RC were significantly larger than in upstream pens. It was difficult to determine if the combined effects of density and location significantly affected release size of fish since the effects were tested differently at SSP (not significant) and RC (significant).

After the initial two weeks, the difference in size among the fed fish in net pens and control fish in the hatchery was accelerated (Fig. 6). Size of control fish in SCNFH were compared with fish in net pens on release date using a planned comparison analysis (Appendix 13). Fish in net pens were significantly larger in all treatments at release than in control fish in the hatchery (Fig. 6).

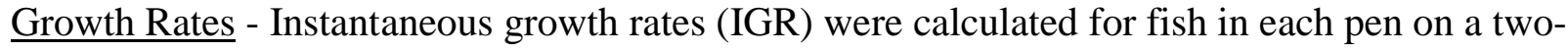
week basis throughout the study. Significantly higher IGR $(\mathrm{P}<0.05)$ were observed during the initial two-week period than during later periods at both SSP and RC (Table 6; Appendix 14). During the remaining 6 weeks IGR at SSP were constant, while at RC, IGR were significantly higher during weeks 3 and 4 than during the later periods. No differentiation was made among different treatments.

Conversion Rates - Conversion rates (weight food fed/weight gain of fish) varied little among fish from different pens at SSP ranging from 1.5-1.7, while rates of conversion at RC tended to be slightly better for fish reared at low density (0.9-1.1 versus 1.2-1.5) (Table 7). Conversion rate of fish held in the hatchery was 1.07 . 


\section{Social Security Pond}
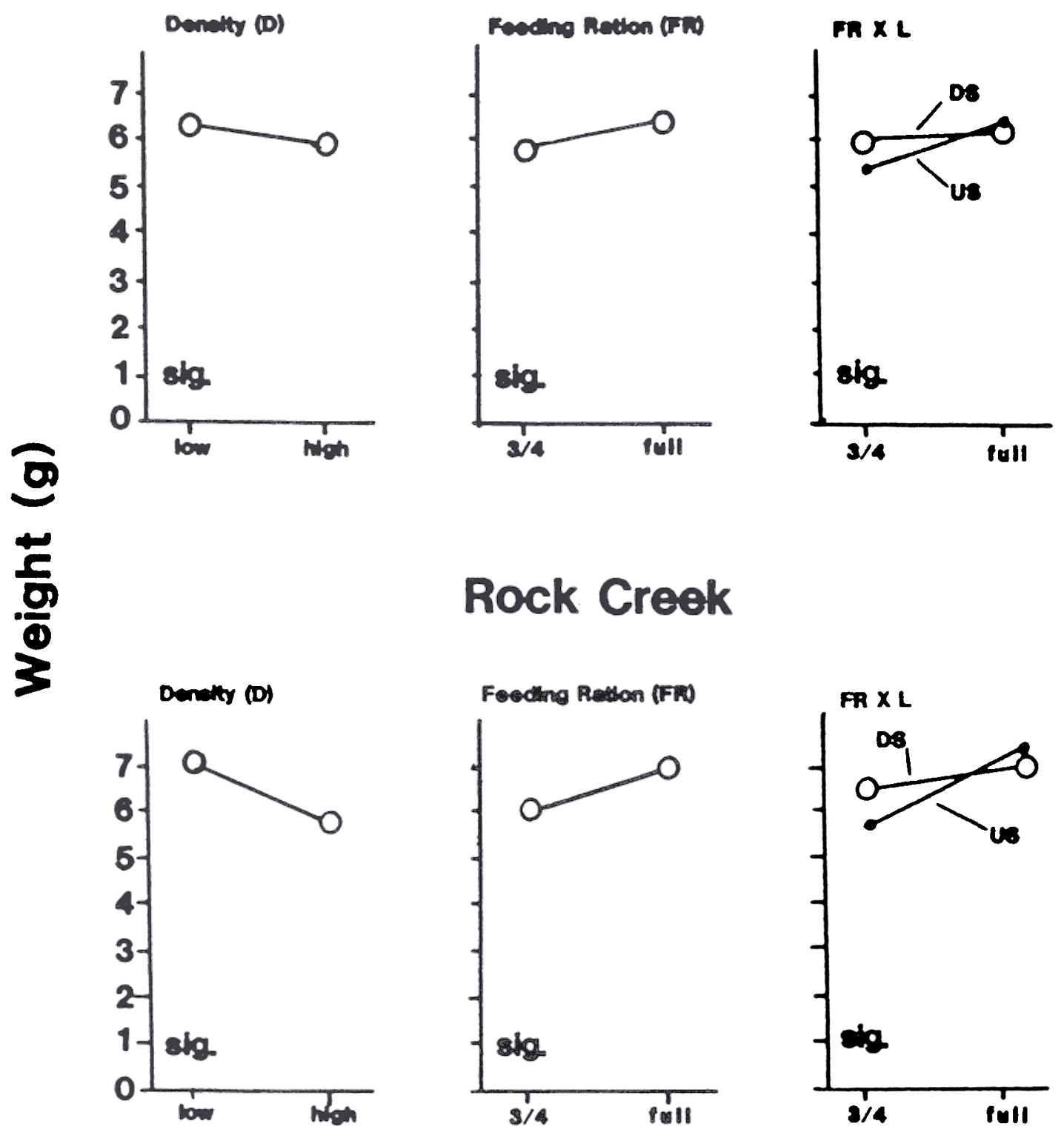

\section{Rock Creok}
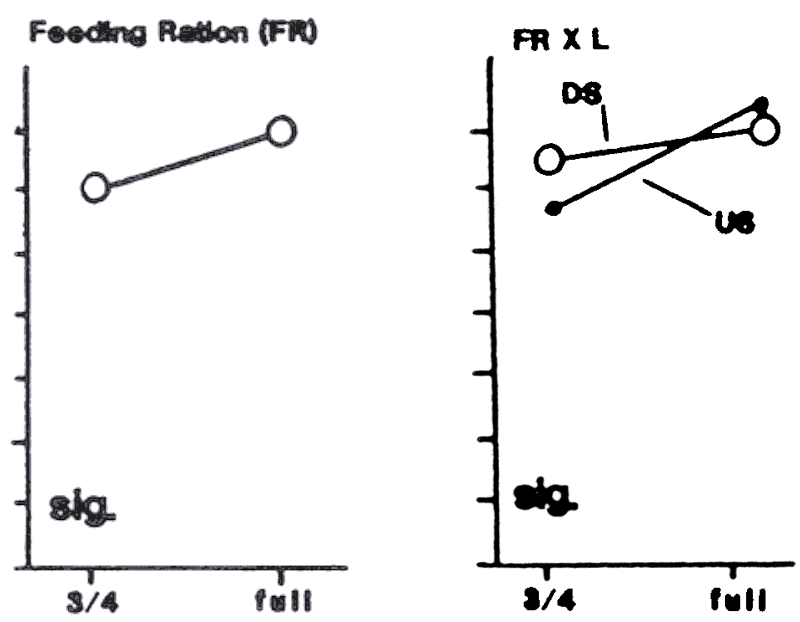

Figure 5. Summarization of significant results of a threeway analysis of variance comparing effects of different feeding rations (FR), densities (D), and pen locations (L) on final release weights of fed fish in pens (US--upstream; DS--downstream). 
HIgh density-full ration

High denelty-3/4 ration

Soclal Securlty Pond

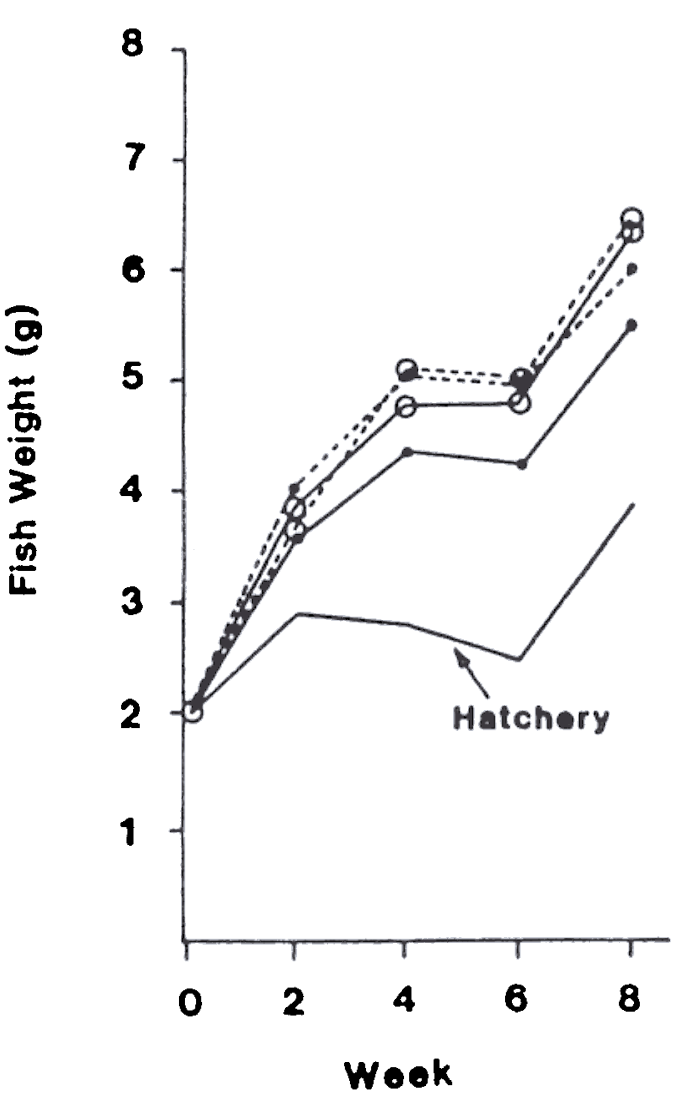

Low density-full ration 0 -.....

Low density-3/4 ration

Rock Creok

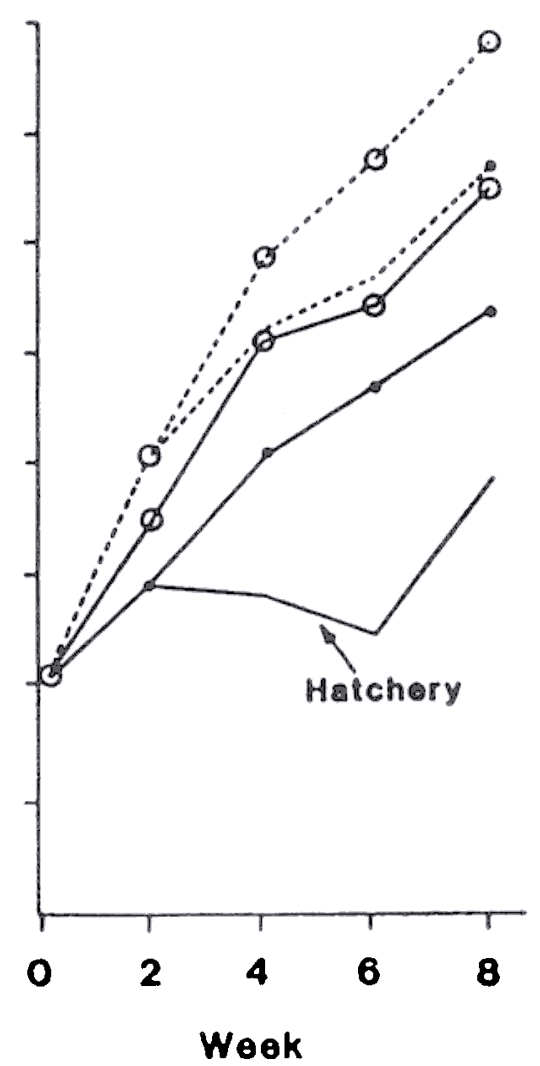

Rock Creek

(Barrier Not Unted Pone)

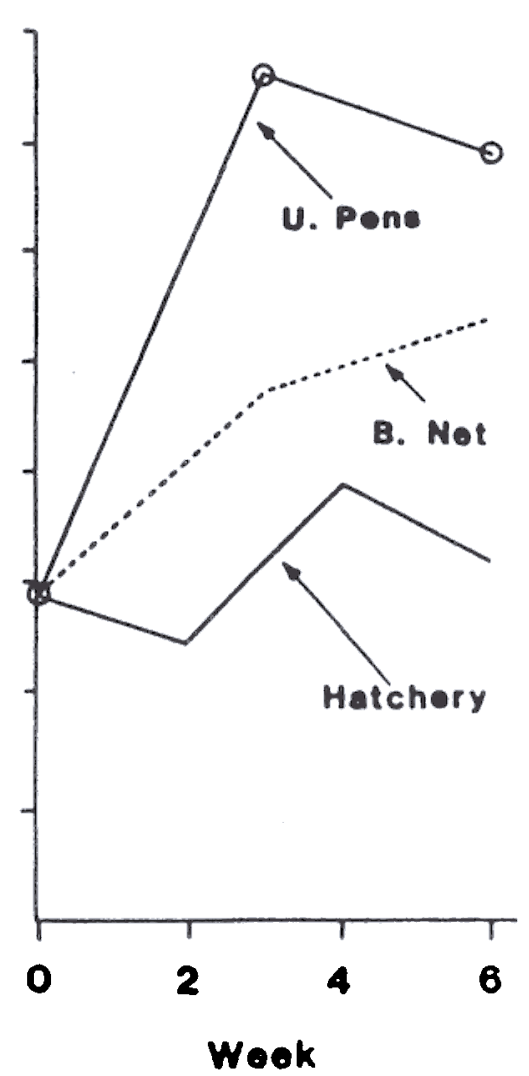

Figure 6. Mean weight of fed fish at various density-feeding combinations and in the hatchery, barrier net, and unfed pens during rearing trials at Social Security Pond and Rock Creek, 1984. 
Gill ATPase and Lipid Levels - Gill Na+-K+ ATPase activity, an indication of fish smoltification, rose to higher levels among fish reared in net pens than fish held in the hatchery (Fig. 7). The first ATPase samples were taken after the fourth week of rearing. Levels by that time had risen to over 24 umoles Pi.mg- ${ }^{1}$ prot.hr- ${ }^{1}$ in both areas. ATPase activity continued to increase during the third week of May, peaking at 42 and 35 a moles Pi.mg- ${ }^{1}$ prot.hr- ${ }^{1}$ at SSP and $\mathrm{RC}$, respectively. Activity during the latter two weeks of rearing declined gradually at RC, but rose quite rapidly at SSP, where levels returned to activities more similar to those recorded in hatchery-reared fish during June. Hatchery fish showed no distinct increases in ATPase activity until the last week of June, but rose gradually during the extended holding period during July and August; levels never reached those observed in the net-pen reared fish.

Total body lipid content ( $\%$ of total body weight), an additional indication of smoltification (Wedemeyer et al. 1981), was analyzed from fish examined for ATPase activity. Receding lipid concentrations were closely associated with observed increases in ATPase activities in fish reared in both areas, as well as in the hatchery (Fig. 7).

\section{$\underline{\text { Rearing of Unfed Fish in Barrier Net and Predator Exclusion Pens }}$}

Densities stocked in the barrier net and in the predator exclusion pens were similar $\left(18 \mathrm{~g} / \mathrm{m}^{3}\right.$ or 0.001 pounds $/ \mathrm{ft}^{3}$ ), totaling 79,442 fish in the barrier net, and 549 and 487 fish in the pens; fish averaged about $160 \mathrm{fish} / \mathrm{lb}$ at stocking (630 fish/kg) (Table 8). Mortality among fish held in the barrier net over the six week period was nearly 30\%; an estimated 55,880 fish were released (Table 8; Appendix 4). Mean growth rate of fish in the barrier net was better than fish reared in the hatchery but less than for unfed fish reared in the pens (Fig. 6); a net increase in mean weight/fish of about $50 \%$ occurred in barrier net fish during the six week period. Because of the mortality, total weight of fish released from the barrier net was only about $18 \%$ higher than weight originally stocked.

No predators were removed from within the barrier net, consequently mortality due to fish predation, as well as bird and mammal predation, was expected. During sampling at release with a $30.3 \mathrm{~m}$ seine, predators captured in the barrier net included black crappie

(Pomoxis nigromaculatus), smallmouth bass (Micropterus dolomieui), yellow perch

(Perca flavescens), largemouth bass (Micropterus salmoides), and one squawfish

(Ptychocheilus oregonensis) (Table 9). Predators taken were regarded only as an indication of 
species composition that might be found in similar situations. About $70 \%$ of predator stomachs ( $\mathrm{N}=19$ ) examined contained reared fish. In addition, bird predation was observed on numerous occasions, but no estimate of bird depredation was possible; mammal predators were not observed during the rearing trials.

In the predator exclusion pens mortality was extremely low, accounting for less than $1 \%$ of the initial numbers (Table 8). Mean growth of fish in predator exclusions pens was higher than in the barrier net resulting in the release of fish from the pens which were about $20 \%$ larger than those in the barrier net; total weight of unfed fish released from the pens was $55 \%$ higher than initial weights stocked. Release weights of unfed fish were significantly higher $(\mathrm{P}<0.05)$ in the pens than in either the barrier net or the same stock reared at the hatchery. However, fish in the barrier net were also significantly larger than those in the hatchery (Appendix 15). The condition factor of fish in the barrier net and pens did not differ greatly from those of fed fish reared in pens (Table 8).

ATPase samples taken from fish reared in the barrier net during the fourth week of rearing were elevated (35.5 umoles Pi.mg- ${ }^{1}$ prot.hr- ${ }^{1}$ ) but declined to about 23 umoles Pi-mg- ${ }^{1}$ prot.hr- ${ }^{1}$ by release date (Table 10). ATPase samples were not taken from fish in predator exclusion pens until release because of sampling difficulties; ATPase values at that time were found to be the same as in the barrier net at release.

Growth rates of fish were substantially higher in the pens and barrier net over the initial four week period than for the last two weeks of rearing (Table 10). 
Table 6. Multiple comparison (Newman - Keuls test) of significant differences in instantaneous growth at Social Security Pond and Rock Creek by time (twoweek periods). Continuously underlined values are not significantly different at 0.05 level.

Social Security Pond:

\begin{tabular}{cccc}
\hline Week 2 & Week 4 & Week 6 & Week 8 \\
\hline .058 & .016 & -.003 & .019 \\
\hline
\end{tabular}

Rock Creek:

\begin{tabular}{cccc}
\hline Week 2 & Week 4 & Week 6 & Week 8 \\
\hline .048 & .021 & .008 & .013 \\
\hline
\end{tabular}


Table 7. Food conversion rate (wt food fed/wt gain) at Social Security Pond and Rock Creek for fish reared at high and low densities and fed full and 3/4 hatchery rations, 1984.

\begin{tabular}{|c|c|c|c|c|c|c|c|c|}
\hline \multirow[b]{2}{*}{ Location } & \multicolumn{2}{|c|}{ High density-full } & \multicolumn{2}{|c|}{ High density-full-3/4 } & \multicolumn{2}{|c|}{ Low density-full } & \multicolumn{2}{|c|}{ Low density-full-3/4 } \\
\hline & 1 & 2 & 3 & 4 & 5 & 6 & 7 & 8 \\
\hline Social Security Pond & 1.5 & 1.6 & 1.7 & 1.5 & 1.6 & 1.6 & 1.6 & 1.5 \\
\hline Rock Creek & 1.5 & 1.4 & 1.3 & 1.2 & 1.0 & 1.1 & 1.0 & 0.9 \\
\hline
\end{tabular}


Table 8. Numbers and pounds of fish stocked, mortality, numbers and pounds of fish released, length-weight gain, and condition factor $(\mathrm{k})$ of unfed fish reared in a barrier net and pens at Rock Creek, 1984.

\begin{tabular}{|c|c|c|c|}
\hline & Barrier net & Unfed 1 & Unfed 2 \\
\hline No. fish stocked & $79,442^{a}$ & 549 & 487 \\
\hline $\begin{array}{l}\text { Natural mortality } \\
(\%)\end{array}$ & $\begin{array}{l}23,562 \\
(29.7)\end{array}$ & $\begin{array}{c}2 \\
(0.4)\end{array}$ & $\begin{array}{c}5 \\
(1.0)\end{array}$ \\
\hline $\begin{array}{l}\text { Sample mortality } \\
(\%)\end{array}$ & $\begin{array}{l}100 \\
(0.1)\end{array}$ & $\begin{array}{c}30 \\
(5.5)\end{array}$ & $\begin{array}{c}31 \\
(6.4)\end{array}$ \\
\hline Total no. released & $55,780 \mathrm{a}$ & 517 & 451 \\
\hline $\begin{array}{l}\text { Pounds fish stocked/ft }{ }^{3} \\
\left(\mathrm{~g} / \mathrm{m}^{3}\right)\end{array}$ & $\begin{array}{l}.001 \\
(18)\end{array}$ & $\begin{array}{l}.001 \\
(18)\end{array}$ & $\begin{array}{l}.001 \\
(18)\end{array}$ \\
\hline $\begin{array}{l}\text { Pounds fish released } / \mathrm{ft}^{3} \\
\left(\mathrm{~g} / \mathrm{m}^{3}\right)\end{array}$ & $\begin{array}{c}.001 \\
(21.2)\end{array}$ & $\begin{array}{c}.003 \\
(46.4)\end{array}$ & $\begin{array}{c}.002 \\
(37.8)\end{array}$ \\
\hline Percent gain & 17.8 & 58.0 & 53.0 \\
\hline $\begin{array}{l}\text { No. fish } / \mathrm{lb} \text { released } \\
\text { (No. fish } / \mathrm{kg} \text { ) }\end{array}$ & $\begin{array}{l}81.9 \\
(181)\end{array}$ & $\begin{array}{c}64.2 \\
(141)\end{array}$ & $\begin{array}{c}68.2 \\
(150)\end{array}$ \\
\hline Condition factor $(\mathrm{k})$ & 1.17 & 1.11 & 1.12 \\
\hline
\end{tabular}

a Population estimate based on Peterson method (Chapman's version) from Ricker 1975

- - see Appendix 4. 
Table 9. Predators (>200 mm) collected from barrier net in Rock Creek, 1984.

\begin{tabular}{|c|c|c|c|c|c|c|c|}
\hline \multirow[b]{2}{*}{ Species } & \multicolumn{6}{|c|}{ Length frequency (mm) } & \multirow[b]{2}{*}{ Total } \\
\hline & $200-249$ & $250-299$ & $300-349$ & $350-399$ & $400-449$ & $450-$ & \\
\hline Largemouth bass & 0 & 0 & 0 & 4 & 3 & 0 & 7 \\
\hline Smallmouth bass & 7 & 7 & 5 & 0 & 0 & 1 & 20 \\
\hline Crappie & 7 & 1 & 0 & 0 & 0 & 0 & 8 \\
\hline Yellow perch & 7 & 3 & 0 & 0 & 0 & 0 & 10 \\
\hline Squawfish & 0 & 0 & 0 & 0 & 0 & 1 & 1 \\
\hline Total & 21 & 11 & 5 & 4 & 3 & 2 & 46 \\
\hline
\end{tabular}


Table 10. Gill Na+-K+ ATPase concentrations and instantaneous growth rates of unfed fish in net-pens and in the barrier net at Rock Creek, 1984.

\begin{tabular}{lcccc}
\hline \multirow{2}{*}{ Week } & \multicolumn{2}{c}{ ATPase Na+-K+ } & \multicolumn{2}{c}{ Instant. growth rates } \\
& Pens & Barrier net & Pens & Barrier net \\
\hline 2 & & - & - & - \\
4 & - & 35.5 & 34 & 22 \\
6 & 23.3 & 23.3 & -4 & 8 \\
\hline
\end{tabular}




\section{DISCUSSION AND CONCLUSION}

Initial estimates of loading densities for rearing upriver bright fall Chinook salmon in net-pens were based on conservative estimates of flows and minimal water exchange (Appendix 3). Therefore, intended high loading densities of about $1.6 \mathrm{~kg} / \mathrm{m}^{3}\left(0.1 \mathrm{lb} / \mathrm{ft}^{3}\right)$ (at release) were probably low in relation to the higher inflows actually observed in to SSP $\left(\approx 1.27 \mathrm{~m}^{3} / \mathrm{s}\right)$ and $\mathrm{RC}$ $\left(\approx 1.13 \mathrm{~m}^{3} / \mathrm{s}\right)$ during the study. Densities commonly regarded as safe for routine net-pen culture of fall Chinook salmon range from 4.0 to $6.4 \mathrm{~kg} / \mathrm{m}^{3}\left(.25-.40 \mathrm{lb} / \mathrm{ft}^{3}\right)$ for fish at about $45 / \mathrm{kg}$ (100/lb) (Senn et al. 1984) (Table 11). In an estuarine situation, however, Chinook salmon have been reared at 10.0-28.2 kg/m 3 (.62-1.75 lb/ft3) (Moring 1982). Maximum density using cage culture for fall Chinook in freshwater may be about $3.9-5.2 \mathrm{~kg} / \mathrm{m}^{3}\left(.24-.32 \mathrm{lb} / \mathrm{ft}^{3}\right)$, three to four times greater than maximum densities held during the 1984 rearing trials. Other anadromous species have been reared at relatively high densities, ranging from 8.0 to $16.0 \mathrm{~kg} / \mathrm{m}^{3}(.50-1.00$ $\left.\mathrm{lb} / \mathrm{ft}^{3}\right)($ Table 11$)$.

However, even at the relatively low stocking densities used during the study, mortalities increased when water temperature exceeded $16 \mathrm{C}$, presumably from ERM disease, and possibly columnaris. Mortality was much less for fish reared at low density, but still increased when temperature exceeded 17 C. Stocking at the higher, theoretical densities may therefore, result in excessive mortality losses.

More pounds of fish per pen were reared at high density, but incidence and mortality from disease were higher. The largest fish were reared in pens containing a low density and fed a full hatchery ration. If rearing space were not a factor, the fish manager may thus be given the option of rearing either higher numbers or larger fish. Rearing at low density would decrease the possibility of disease outbreak and produce optimum growth rates. In addition, recent evidence indicates that coho salmon (0. $\underline{\text { kisutch }})$ reared in hatcheries at lower densities had better survival rates (recovered in the fishery and escapement) than those reared at higher densities (Fagerlund et al. 1981; Sandercock and Stone 1982).

Placement of net pens in relation to one another may be a consideration at reduced feeding rations because of the observed differences in growth during the present study, especially if fish in several adjacent net pens are being reared to a desired, uniform release size. At full feeding rations, however, pen placement may not be as important, and growth, at least at the densities 
used in the present study, would probably not be inhibited by location. Fish in the barrier net and predator exclusion pens responded favorably to being held at a very low density in an environment with no food supplement. Growth of fish held in both enclosures was greater than for fish in the hatchery. Apparently, estimated amounts of available food were sufficient to support the densities held in these enclosures. No disease was observed in either of the test groups, but diseased fish would have been difficult to recover from the barrier net. Estimated mortalities in the barrier net were not excessive considering the relatively high number of predators collected from the enclosure and unmeasured bird and mammal predation.

The barrier net may be advantageous in areas where water temperatures increase above $16 \mathrm{C}$ since fish are able to seek out cooler temperatures in deeper waters within the enclosure. Holding periods could be extended until a desired size or stage of development was reached. Routine observations of fish in the barrier net were impossible because of their wariness. Those fed in the net-pens, however, apparently became habitualized to daily maintenance of the pens since they showed a lack of normal animal-avoidance behavior when disturbed. Fish reared in an enclosure exposed to predators may be less disoriented and confused at release because of their normal avoidance behavior, resulting in increased smolt survival, especially during the early stages of out-migration.

Size of fish at release was a primary consideration when releasing smolts for optimum outmigration. Fall chinook smolts have a greater chance of survival when released at about $70 \mathrm{~mm}$ in length or larger ( $\approx 95$ fish/lb) (Wagner et al. 196; Gould et al. 1983). Fish reared at high density in pens in 1984 averaged about $83 \mathrm{~mm}$ in length $(\approx 71 \mathrm{fish} / \mathrm{lb})$ at release; those reared at low density in pens at both sites were slightly larger at release.

Temperatures are also an essential consideration for selection of rearing strategies and release criteria. Temperatures encountered at RC and SSP during the present study were not lethal to fall chinook (Brungs and Jones 1977), but disease increases were associated with temperature increases above 15-16 C. Most backwaters along the Columbia River commonly reach temperatures above 15 C by mid-June (Parente and Smith 1981); acclimation ponds may warm even faster, depending on water source and exchange rate. 
Table 11. Loading densities used, or recommended for culturing salmonids in net-pen enclosures (pounds/ $/ \mathrm{ft}^{3}$ in parentheses). (Loading densities based on maximum water temperatures of 15-16C).

\begin{tabular}{|c|c|c|}
\hline Source & Species & Density $\left(\mathrm{kg} / \mathrm{m}^{3}\right)$ \\
\hline Squaxin Island Sea Farms ${ }^{\mathrm{a}}$ & coho & $12.0(.75)$ \\
\hline Quinault Tribal Hatchery ${ }^{\mathrm{b}}$ & coho \& steelehead & $8.0-12.0(.50-.75)$ \\
\hline$"$ & chinook & $8.0-10.0(.5-.6)$ \\
\hline Moring (1982) & chinook & $10.0-28.2(.62-1.75)$ \\
\hline Senn et al. (1984) & coho \& steelehead & $12.0-16.0(.75-1.00)$ \\
\hline$"$ & yearling chinook \& sockeye & $8.0-12.0(.50-.75)$ \\
\hline$"$ & fall chinook & $4.0-6.4(.25-.40)$ \\
\hline \multicolumn{3}{|l|}{ Present Study } \\
\hline full ration-"high" density & fall chinook & $0.64(.04)$ \\
\hline 3/4 ration-"low" density & fall chinook & $0.05(.003)$ \\
\hline Barrier net/pens (unfed fish) & fall chinook & $3.9-5.2(.24-.32)$ \\
\hline Maximum density & & \\
\hline
\end{tabular}

a Personal communication, T. Tynor, Hatchery Manager, Squaxin Island Sea Farm.

b Personal communication, M. Figg, Hatchery Manager, Quinault Tribal Hatchery.

c Maximum recommended loading densities for Columbia River reared fish interpolated from loading densities developed for hatchery ponds (Wedemeyer et al. 1981). 
Some measure of smoltification on release is desirable to determine readiness of the smolts for ocean entry. Wedemeyer et al. (1981) suggested seawater challenge, blood sodium tests as the best physiological indicator of smoltification. Gill Na+-K+ ATPase activity can also be used as an indication of smoltification, and may yield similar results to seawater challenge (personal communication, W. Zaugg, National Marine Fisheries Service, Cook, Washington). Gill ATPase activity levels above 20 u moles Pi.mg- ${ }^{1}$ prot.hr- ${ }^{1}$ are considered indicative of the onset of smoltification during the present study.

Future releases of upriver bright fall chinook salmon for this study will be coordinated with: 1) size--better survival and return of fish exceeding $70 \mathrm{~mm}$ (95 fish/lb) at release can be expected; 2) smoltification activity--gill ATPase activity above $20 \mathrm{u}$ moles Pi.mg- ${ }^{1}$ prot.hr- ${ }^{1}$ is an indication of the physiological development of the fish from parr to smolt; and 3) water temperatures--water temperatures above $16 \mathrm{C}$ were associated with significantly increased mortalities.

Figure 8 summarizes these criteria for fish reared at high density-full ration during 1984. At both sites the above criteria were satisfied after the third or fourth week of rearing in net-pens. Fish were held for an extended period of time during 1984 in order to fully evaluate the effects of higher water temperatures. Future releases will be coincidental with the above criteria unless unforeseen problems develop.

Stocking net pens at lower densities provides the option of rearing larger fish for release with lessened chance of disease, while at higher densities risk of disease may be greater, but larger numbers of fish can be produced using fewer facilities. The higher stocking rates thus produce maximum pounds of fish per available rearing space. In order to produce fish at the lowest cost, while maintaining acceptable growth rates, fish in 1985 net-pen studies will be reared at 440 $\mathrm{g} / \mathrm{m}^{3}\left(.027 \mathrm{lb} / \mathrm{ft}^{3}\right)$. Fish in the barrier net will be reared at low-density and exposed to predation.

Future releases of fish will take place according to three criteria identified as critical or optimum, given similar conditions as those observed during 1984 rearing trials. Fish will be reared to at least 209/kg (95/lb), providing water temperatures do not rise above $16 \mathrm{C}$ for an extended period of time. Elevated gill-ATPase levels above 20 u moles Pi.mg- ${ }^{1}$ prot.hr- ${ }^{1}$ will be an indication of smoltification and readiness for seawater entry. 


\section{Social Security Pond}

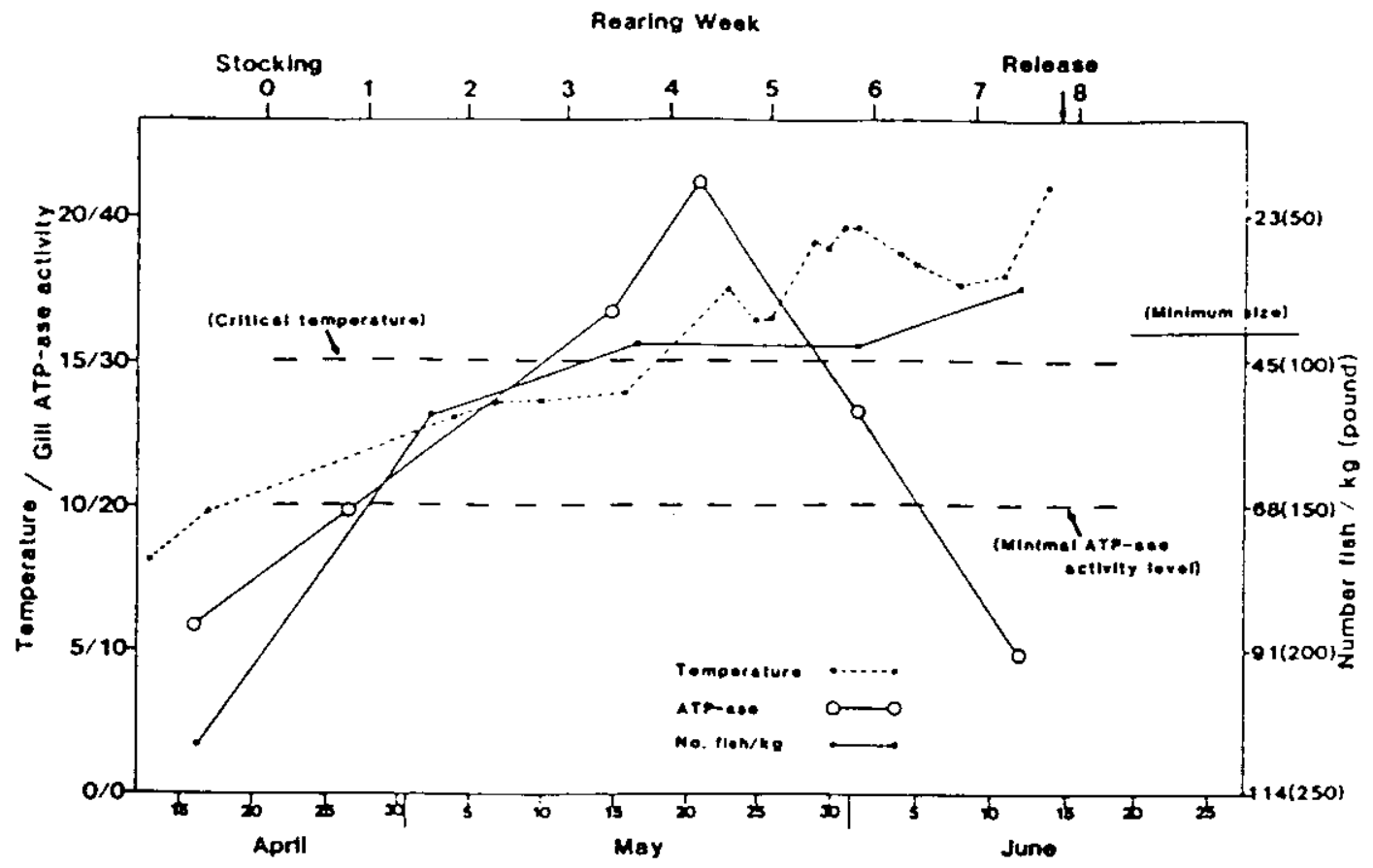

\section{Rock Creek}

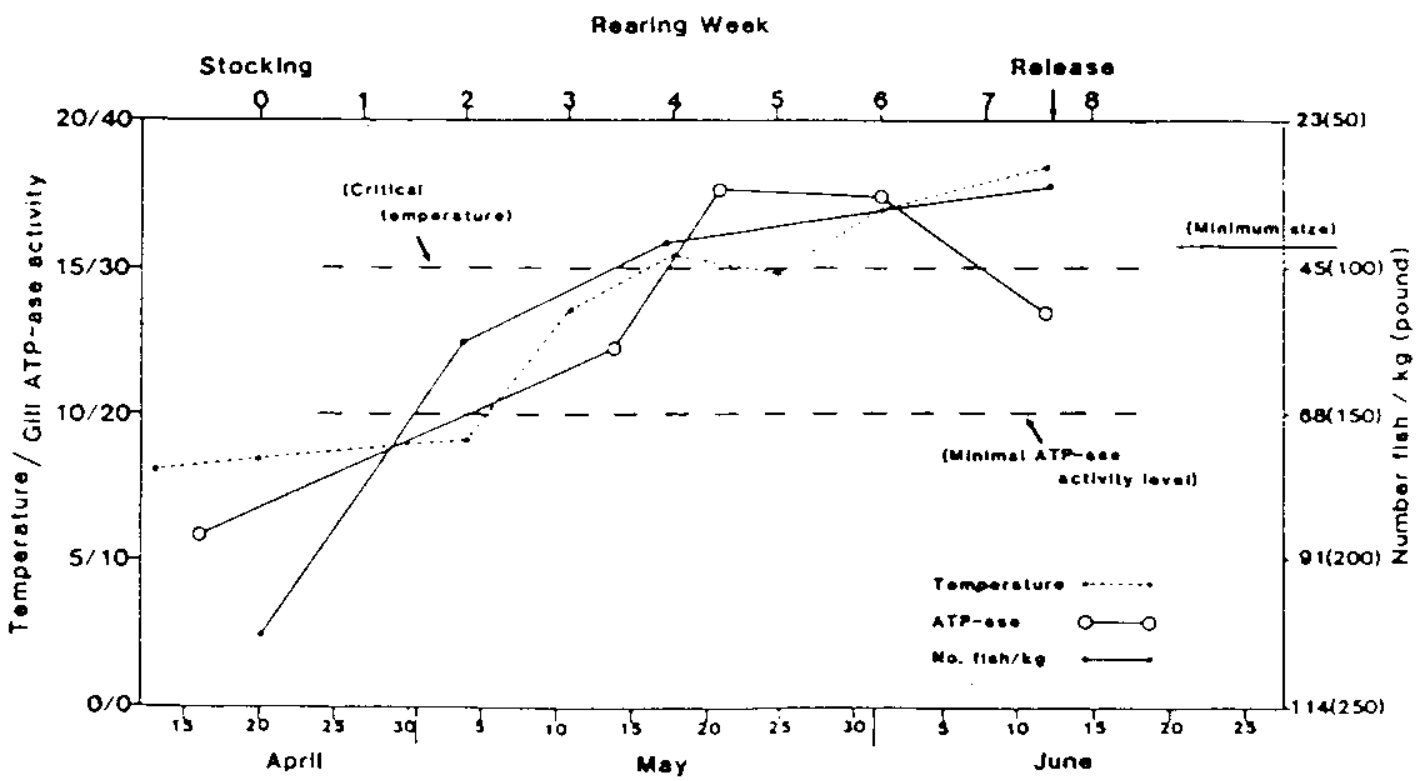

Figure 8. Summarization of selected criteria for future releases compared with observed growth, water temperatures and smoltification activity for fish held at high density at Social Security Pond and Rock Creek, 1984. 


\section{ACKNOWLEDGEMENTS}

We thank Pedro Veliz for incomparable courage and stamina, Wally Zaugg for ATPase analyses and advice, the Bioenergetics staff at the Willard Field Station for lipid analyses, and the personnel at Spring Creek National Fish Hatchery for providing high quality fish for outplanting.

We also extend our personal appreciation to Darrel Sunday and Cliff Ellsmore of the U.S. Army Corps of Engineers for onsite coordination and assistance. 


\section{REFERENCES CITED}

Bardach, J.E., J.H. Ryther, and W.O. McLarney. 1972. Aquaculture: The farming and husbandry of freshwater and marine organisms. Wiley Interscience, a Division of John Wiley and Sons, In c., New York, N.Y. 868 pp.

Brungs, W.A. and B.R. Jones. 1977. Temperature criteria for freshwater fish: protocol and procedures. Environmental Protection Agency Report Number 600/3-77-061, U.S. Environmental Protection Agency, Duluth, Minnesota. 129 pp.

Committee on Water Quality Criteria. 1973. Water Quality Criteria. Prepared for the U.S. Environmental Protection Agency by the National Academy of Sciences, National Academy of Engineering. U.S. Government Printing Office, Washington D.C.

Denel, C.R., D.C. Haskell, and A.V. Tunison. 1942. The New York State fish hatchery feeding chart. Fisheries Research Bulletin No. 3, New York State Conservation Dept., Bureau of Fish Culture, Albany, N.Y.

Fagerlund, U.H.M., J.R. McBride, and E.T. Stone. 1981. Stress related effects of hatchery rearing density on coho. Trans. Am. Fish Soc. 110:644-649.

Gould, R.W., A.N. Palmisano, S.D. Smith, C.V.W. Mahnken, W.S. Zaugg, and E.F. Prentice. 1985. Seawater acclimation of premigratory (presmolt) fall Chinook salmon: A possible new management strategy? In: Carl J. Sindermann (ed), Proc. of 11th U.S. - Japan Meeting on Aquaculture, Salmon Enhancement, Tokyo, Japan, Oct. 19-20, 1982. pp. 15-19. (NOAA Tech. Rep. NMFS 27)

Krenkel, P.A. and V. Novotny. 1984. Water Quality Management. Academic Press, Inc., New York. $671 \mathrm{pp}$.

Leitritz, E, and R.C. Lewis, 1980. Trout and salmon culture (Hatchery Methods). California Fish Bulletin Number 164. 197 pp.

Moring, J.R. 1982. Fin erosion and culture-related injuries of Chinook salmon raised in floating net pens. Prog. Fish-Cult. 44(4):189-191. 
Novotny, J.F., T.L. Macy, and J.T. Gardenier. 1984. Pen rearing and imprinting of fall Chinook salmon: Annual Report 1983. Prepared for Bonneville Power Administration by U.S. Fish and Wildlife Service. 25pp.

Parente, W.D. and J.G. Smith. 1981. Columbia River backwater study, Phase II. U.S. Fish and Wildlife Service, Fisheries Assistance Office, Vancouver, Washington. 87 pp.

Piper, R.G., I.B. McElwain, L.E. Orme, J.P. McCraren, L.G. Fowler, and J.R. Leonard. 1982. Fish Hatchery Management. U.S. Fish and Wildlife Service, Washington D.C. 517 pp.

Ricker, W.E. 1975. Computation and interpretation of biological statistics of fish populations. Bull. of the Fish. Res. Board of Can. 191:78-79.

Rondorf, D.W., G.A. Gray, R.B. Fairley, R.S. Gardner, W.R. Nelson. In preparation. Relative abundance, distribution and feeding biology of subyearling salmon in a Columbia River reservoir. U.S. Fish and Wildlife Service, Seattle National Fishery Reasearch Center, Willard Field Station, Cook, Washington.

Sandercock, F.K. and E.J. Stone. 1982. A progress report on the effect of rearing density on subsequent survival of capilano coho. Proc. No. Pac. Aquaculture Symp., Aug 1980, Anchorage, Alaska. p. 151.

Senn, H., J. Mack, and L. Rothfus. 1984. Compendium of low-cost Pacific salmon and steelhead trout production facilities and practices in the Pacific Northwest. Pub. by Division of Fish and Wildlife, Bonneville Power Administration, Portland, OR. 488 pp.

Sokal, R.R. and F.J. Rohlf. 1981. Biometry: The principles and practices of statistics in biological research. W.H. Freeman and Company, San Francisco. 859 pp.

U.S. Environmental Protection Agency. 1976. Quality Criteria for Water. Washington, D.C. $256 \mathrm{pp}$.

Wagner, H.H., F.P. Conte, and J.L. Fessler. 1969. Development of osmotic and ionic regulation in two races of Chinook salmon Oncorhynchus tshawytscha. Comp. Biochem. Physio. Vol. 29:325-341. 
Wedemeyer, G.A., R.L. Saunders, and W.C. Clarke. 1981. The hatchery environment required to optimize smoltification in the artificial propagation of anadromous salmonids. Pages 6-20 in L.J. Allen and E.C. Kinney, eds. Proceedings of the Bio-Engineering Symposium for Fish Culture. Section, American Fisheries Society, Bethesda, MD.

Zaugg, W.S. 1982. A simplified preparation for adenosine triphosphatase (ATPase) determined in gill tissue. Can. J. Fish Aquat. Sci. 39:215-217. 
Appendix 1. Water quality at beginning, mid-point, and end of studies at Social Security Pond, 1984. Relation of measured parameters to desirable criteria are included. Samples analyzed by Laucks Testing Laboratories, Inc., Seattle, Washington (data recoreded as $\mathrm{mg} / 1$ ).

\begin{tabular}{|c|c|c|c|c|}
\hline Parameter & $4 / 2$ & $5 / 16$ & $6 / 15$ & Criteria $^{a, b, c}$ \\
\hline Alkalinity as $\mathrm{CaC} 03$ & 72.0 & 66.0 & 54.0 & $>20.0$ \\
\hline Hardness as $\mathrm{CaCO} 3$ & 79.0 & 68.0 & 52.0 & $0-75.0$ (soft) \\
\hline Nitrate \& Nitrate as N & .25 & .13 & $<.05$ & 10.0 \\
\hline Ammonia as $\mathrm{N}$ (un-ionized & .01 & $<.01$ & $<.01$ & .02 \\
\hline Ortho Phosphate as $\mathrm{P}$ & .058 & .021 & .018 & $<.70$ \\
\hline Sulfate as $\mathrm{SO}_{4}$ & 16.0 & 13.0 & 12.0 & $<.50$ \\
\hline Chloride & 6.0 & 4.0 & 2.0 & $<.40$ \\
\hline Cadmium & $<.002$ & $<.002$ & $<.002$ & $<.0004-.0012$ \\
\hline Calcium & 21.0 & 19.0 & 14.0 & --- \\
\hline Colbalt & $<.10$ & $<.01$ & $<.02$ & $\begin{array}{c}<.10-<.05 \\
\text { (background) }\end{array}$ \\
\hline Copper & .004 & $<.005$ & $<.005$ & .10 LC 96 \\
\hline Iron & 1.00 & 1.20 & .42 & $<1.0$ \\
\hline Lead & $<.005$ & $<.010$ & $<.01$ & $\begin{array}{c}<.01 \mathrm{LC} 96 \\
50\end{array}$ \\
\hline Manganese & .014 & .017 & .010 & $<.10$ \\
\hline Magnesium & 6.5 & 5.5 & 4.6 & $<125.0$ \\
\hline Molybdenum & $<.02$ & $<.02$ & $<.05$ & $<1.0$ \\
\hline Sodium & 18.0 & 9.0 & --- & $<75.0$ \\
\hline Zinc & .015 & .011 & --- & $\begin{array}{c}.01 \mathrm{LC} 96 \\
50\end{array}$ \\
\hline
\end{tabular}

a U.S. Environmental Protection Agency, 1976.

b Krenkel, P.A. and V. Novotny, 1984.

c Committee on Water Quality Criteria, 1972. 
Appendix 2. Water quality at beginning, mid-point, and end of studies at Rock Creek, 1984. Relation of measured parameters to desirable criteria are included. Samples analyzed by Laucks Testing Laboratories, Inc., Seattle, Washington (data recoreded as $\mathrm{mg} / 1)$.

\begin{tabular}{lcccc}
\hline \multicolumn{1}{c}{ Parameter } & $4 / 24$ & $5 / 16$ & $6 / 15$ & Criteria $^{\text {a,b,c }}$ \\
& & & & \\
\hline Alkalinity as CaC03 & 68.0 & 72.0 & 44.0 & $>20.0$ \\
Hardness as CaC03 & 65.0 & 66.0 & 600 & $0-75.0$ (soft) \\
Nitrate \& Nitrate as N & 1.3 & .09 & .06 & 10.0 \\
Ammonia as N & $<.01$ & $<.01$ & $<.01$ & .02 \\
Ortho Phosphate as P & .033 & .037 & .028 & $<.70$ \\
Sulfate as SO $\mathrm{SO}_{4}$ & 5.0 & 7.0 & 35.0 & $<.50$ \\
Chloride & 2.0 & 3.0 & $<1.0$ & $<.4 .00$ \\
Cadmium & $<.002$ & $<.002$ & $<.002$ & $<.0004-.0012$ \\
Calcium & 14.0 & 15.0 & 15.0 & --- \\
Colbalt & $<.10$ & $<.10$ & $<.02$ & $<.10-<.05$ \\
& & & & $($ background) \\
Copper & .002 & $<.005$ & $<.005$ & $.10 \mathrm{LC} 96$ \\
& & & & 50 \\
Iron & .36 & .32 & .36 & $<1.0$ \\
Lead & $<.005$ & $<.010$ & $<.01$ & $<.01 \mathrm{LC} 96$ \\
& & & & 50 \\
Manganese & .046 & .064 & .061 & $<.10$ \\
Magnesium & 7.4 & 6.8 & 7.2 & $<125.0$ \\
Molybdenum & $<.02$ & $<.02$ & $<.05$ & $<1.0$ \\
Sodium & 13.0 & 8.7 & 8.0 & $<75.0$ \\
Zinc & .006 & .006 & .003 & $.01 \mathrm{LC} 96$ \\
& & & & 50 \\
& & & & \\
\hline
\end{tabular}

a U.S. Environmental Protection Agency, Quality Criteria for Water, 1976.

b Krenkel, P.A. and V. Novotny, 1984.

c Committee on Water Quality Criteria, 1972. 
Appendix 3. Calculations for estimating fish density in high density pens based on streamsource inflows of $5 \mathrm{cfs}, 16 \mathrm{C}$, suitable water quality, and release weights of about 45 fish/lb (Leitritz and Lewis 1976).

$\underline{\text { Stocking estimates }}$

A. Pond capacity $-8,319,960 \mathrm{ft}^{3}$

Inflow $\quad-300 \mathrm{ft}^{3} /$ minute

Turnover rate $=\left(8,319,960 \mathrm{ft}^{3}\right) /\left(300 \mathrm{ft}^{3} /\right.$ minute $)=27,733$ minutes

B. Length of pond - $1,500 \mathrm{ft}$

$\underline{\text { Water movement through pond }}=\left(1,500 \mathrm{ft}^{3}\right) /(27,733$ minutes $)=0.054 \mathrm{ft} /$ minute

C. Pen exchange

$20 \mathrm{ft} X 7 \mathrm{ft}$ (pen dimensions) x $0.054 \mathrm{ft} /$ minute (flow through pen) $=7.56 \mathrm{ft}^{3} /$ minute

$7.56 \mathrm{ft}^{3} /$ minute $x 7.48$ gallons $/ \mathrm{ft}^{3}=56.6$ gallons $/$ minute exchange

D. Maximum ponds loading at $61 \mathrm{C}$ and 5 c.f.s. inflow is $5.01 \mathrm{lbs} /$ gallon/minute (Leitritz and Lewis 1980)

$(5.01 \mathrm{lbs} /$ gallon/minute $) \times(56.6$ gallons $/$ minute exchange $)=283.31$ pounds $/$ pen

E. Number of fish stocked with a projected release weight of 45 fish/lb

At release:

$(283.31$ pounds/pen $) \times(45 \mathrm{fish} / \mathrm{lb})=12,750 \mathrm{fish} / \mathrm{pen}$

$$
===
$$

At stocking:

(accounting for estimated mortality of aout 25\%/pen)

$12,750+4500(25 \%$ mortality of original stock $)=17,000-17,500 \mathrm{fish} / \mathrm{pen}$

F. Pen capacity at release in pounds $/ \mathrm{ft}^{3}$

$(283.31$ pounds/pen $) /\left(2800 \mathrm{ft}^{3}\right.$-pen volume $)=0.1 \mathrm{lbs} / \mathrm{ft} 3\left(1.6 \mathrm{~kg} / \mathrm{m}^{3}\right)$

$====$ 
Appendix 4. Calculations and assumption for estimating food available for fish in Rock Creek (Estimates were based on a 30-day period).

Zooplankton - Turnover rate in Rock Creek was estimated to be 3.67 days based on an average flow of $4.25 \mathrm{~m}^{3} / \mathrm{s}$ and a volume of 1015 acre-feet. Generation time of Daphnia was assumed to be 30 days for these calculations; no other zooplankton species were included.

1940/m³ Daphnia in Casey Pond, 6-7-81 (Rondorf in review)
A. $1940 / \mathrm{m}^{3}$ x $.00073 \mathrm{~g} \overline{(\mathrm{X}}$ wt.of Daphnia $)=1.42 \mathrm{~g} / \mathrm{m}^{3}$
B. $1.42 \mathrm{~g} / \mathrm{m}^{3}$ x $4 \mathrm{~m} \overline{(\mathrm{X}}$ depth $)=5.68 \mathrm{~g} / \mathrm{m}^{2}$ standing crop
C. $5.68 \mathrm{~g} / \mathrm{m}^{3} \times \underline{30 \text { day period }}=46.43 \mathrm{~g} / \mathrm{m}^{2} / 30$ day
3.67 day turnover rate (available over 30 days)
D. $\frac{46.43 \mathrm{~g} / \mathrm{m}^{2}}{30 \text { day period }}=1.55 \mathrm{~g} / \mathrm{m}^{2}$ available per day over 30 day period

Benthos - Generation time for benthos was assumed to be 30 days for this period of the year. 4040 Oligochaeta and 852 Chironomidae/m² in Rock Creek, fall, 1983 (Novotny et al. 1984)
A. Oligochaeta 4040/m2 x.000250 (X wt.of Oligochaeta $)=1.01 \mathrm{~g} / \mathrm{m}^{2}$
B. Chironomidae $852 / \mathrm{m}^{2}$ x $.000129 \overline{\text { X }}$ wt. of Chironomidae $<7 \mathrm{~mm}$ in length $=0.11 \mathrm{~g} / \mathrm{m}^{2}$
C. $1.01 \mathrm{~g}$ Oligochaeta $/ \mathrm{m}^{2}$
$0.11 \mathrm{~g}$ Chironomidae $/ \mathrm{m}$
$1.22 \mathrm{~g} / \mathrm{m}^{2}$ available over 30 day period
D. $1.12 \mathrm{gm}^{2}=0.04 \mathrm{~g} / \mathrm{m}$ available/day 30-days
Terrestrial Drift - Turnover rate assumed to be 3 times/day (blow in and drift). $.00802 \mathrm{~g} / \mathrm{m}^{2}$ terrestrial drift availale (Rondorf in review)

A. $.00802 \mathrm{~g} / \mathrm{m}^{2}$ x 3 turnover times/day $=.02406 \mathrm{~g} / \mathrm{m} 2$ day

B. $.02406 \mathrm{~g} / \mathrm{m}^{2}$ available/day

$\begin{array}{llll}\text { Summary } & \text { A. Zooplankton } & - & 1.55 \mathrm{~g} / \mathrm{m}^{2} \\ & \text { B. Benthos } & - & .04 \mathrm{~g} / \mathrm{m}^{2} \\ \text { C. Terrestrial Drift } & - & .024 \mathrm{~g} / \mathrm{m}^{2}\end{array}$

Total available food $/$ day $=1.614 \mathrm{~g} / \mathrm{m}^{2}$ 
Appendix 5. Calculations for estimating number of fish that could be raised/hectare based on estimated food available. ${ }^{\text {a }}$

\section{$\underline{\text { Barrier Net }}$}
A. Total available food (Appendix Table 4) $=1.614 \mathrm{~g} / \mathrm{m}^{2}$
B. $1.614 \mathrm{~g} / \mathrm{m} 2=18,300 \mathrm{~g} / \mathrm{ha}$ food available/day
C. $5.0 \mathrm{~g}$ fish $\times 1.5 \%$ of body weight (minimum $=.075 \mathrm{~g} /$ day intake for maintenance and growth)
D. $.075 \mathrm{~g} / \mathrm{day}$ (food demand of $5 \mathrm{~g}$ fish)
E. $18,300 \mathrm{~g} / \mathrm{ha}$
$.075 \mathrm{~g}$ required/day
$=244,000 \mathrm{fish} / \mathrm{ha}$ could be sustained on the calculated food available
F. 244,000 fish/ha $x .24$ ha (barrier net surface area)
$=58,600 \mathrm{fish} / \mathrm{ha}$ could be sustained in barrier net
G. Assuming $25 \%$ predator and disease
$=73,250$ fish required initially to mortality: 58,600 fish/ha x 1.25 ensure release of 55,000 fish.

\section{$\underline{\text { Predator Exclusion Pens }}$}

Only zooplankton were considered in calculation of available food in unfed pens since they were enclosed and covered, making entry of terrestrial drift and benthos difficult.
A. $1.42 \mathrm{~g} / \mathrm{m} 3$ Daphnia available x $78.4 \mathrm{~m} 3$ (pen volume) $=111.3 \mathrm{~g}$
B. $111.3 \mathrm{~g} \mathrm{x} 30$ days
3.67 turnover rate
$=909.8 \mathrm{~g}$ available over 30 days
C. $909.8 \mathrm{~g}$ 30 day period
$=30.3 \mathrm{~g}$ zooplankton available/day
D. $30.3 \mathrm{~g}$ $.075 \mathrm{~g}$ required/day
$=404$ fish could be reared in unfed pens with the calculated amount of food available.
E. Assuming 25\% mortality (disease): 404 fish x $1.25=505$ fish required initially to ensure release of 400 fish.

a These calculations allow for a wide margin or error and wre intentionally underestimated to ensure that an adequate food fase was available in both areas. (e.g. Copepods and periphyton associations were excluded, both of which may add a sizable input of usable food organisms to the juvenile fall chinook diet. However, no estimate could be made for either of these potential food components because of the lack of data from which biomass estimates could be determined.) 
Appendix 6. Estimate of numbers of fish released from barrier net on 6-26-84 based $\mathrm{n}$ Peterson formular (Chapman version) from Ricker 1975

$$
\left(\mathrm{N}=\frac{(\mathrm{M}+1)(\mathrm{C}+1)}{\mathrm{R}+1}\right)
$$

Summary:

5-15-84 79,442 fish stocked in barrier net enclosure.

6-13-84 Marked fish $(16,258)$ and unmarked fish $(820)$ placed in barrier net.

6-20-84 Barrier net area sampled with $30.3 \mathrm{~m}$ seine pre-dawn (514 marked and 1,877 unmarked fish recovered in sample).

Calculations:

$M=16,258$ marked fish released in barrier net.

$\mathrm{C}=2,391$ total fish in seine sample.

$\mathrm{R}=514$ marked fish in seine sample.

A. $\mathrm{N}=\underline{(16,258+1)(2,391+1)}=\underline{75,518}$ fish in barrier net on 6-20-84 $514+1$

B. $75,518-17,078$ (stocked on 6-13) $=58,440$ total fish remaining in barrier net as of 6-20-84 from initial stocking.

C. 79,442 (initial stocking) - $58,440=21,002$ mortality over first 36 days $(0.73 \% /$ day)

D. $0.73 \%$ (mortality/day) $\times 6$ days until release $=$ additional $4.4 \%$

E. $58,440 \times 4.4 \%=2,560$ fish mortality expected $6-20$ to $6-26{ }^{a}{ }^{a}$

F. $58,440-2,560=55,880$ total fish released from initial stock.

a Assuming rates of mortality remained relatively constant. 
Appendix 7. Summary of disease analysis completed by the Lower Columbia River Fish Health Center.

Date Summary of activity or finding

5-15-84 Nine-ten fish from each fed pen were taken for disease examination (80 total from Social Security Pond and 75 total from Rock Creek) and transferred to L.C.R. Health Center for analysis.

Findings:

a. 155 fish examined for virus - all negative

b. 60 fish examined for bacterial kidney disease (30 from each area - all negative)

c. 9 fish from Rock Creek examined for enteric redmouth disease (ERM) - 6 positive

d. 12 fish from Social Security Pond examined for enteric redmouth disease - 9 positive

5-26-84 Thirty-four fish from Social Security Pond examined after a sizable increase in mortalities.

- 29 positive for ERM

- 5 negative for ERM

6-13-84 Miscellaneous sample taken from release group at Rock Creek had columnaris. Additional diseases were not detected in either release group. 
Appendix 8. Chronological schedule of events for upriver bright chinook salmon rearing, transfer, and release for 1984 pen rearing studies.

September 1-30, 1983 Adults captured in the Bonneville Hatchery (Oregon Dept. of Fish \& Wildlife) fish traps and from the fish ladder at Bonneville Dam and held at Bonneville Hatchery for spawning.

December 1-22, 1983 Eggs taken at Bonneville Hatchery and transferred to Spring Creek National Fish Hatchery.

February 4, $1984 \quad$ Fish ponded at Spring Creek Hatchery and rearing begun. Water temperature $-11^{\circ} \mathrm{C}$, fed Biodiet ${ }^{\mathrm{a}}$ mash.

February 14-17

Fish treated with Hyamine 1622 (50\%) in ponds at Spring Creek Hatchery.

March 9-18

Fish fed Biodiet grower granules (.8 mm size) and treated with TM-50 plus sulfamerazine ( $3 \mathrm{~g}$ teramycin plus $3 \mathrm{~g}$ sulfamerazine/100 pounds of fish).

March 29 - April $3 \quad$ Fish wre adipose-fin clipped and coded wire tagged at 400/lb.

April $4 \quad$ Fish were treated with Hyamine $1622(50 \%)$ for one hour at a consentration of 1:250,000.

April 12

Fish were again treated with Hyamine (as on April 4)

April 14-18

Fish fed Biodiet grower granules (.8 mm size) and treated with TM - 50 plus sulfamerazine ( $3 \mathrm{~g}$ teramycin plus $3 \mathrm{~g}$ sulfamerazine/100 pounds of fish).

April $18 \& 20$

Fish were transferred to fed pends at Social Security Pond (4-18) and Rock Creek (4-20) at about 225/lb. Water termperatures $12^{\circ} \mathrm{C}$ at Social Security Pond and $9^{\circ} \mathrm{C}$ at Rock Creek.

May 15

Fish transferred to barrier net and predator exclusion pens at Rock Creek. Weight $160 / \mathrm{lb}$; water temperature $13^{\circ} \mathrm{C}$.

June $13 \& 14 \quad$ Fish released from pends at Rock Creek (6-13) and Social Security Pond (6-14).

June 26

Fish released from barrier net and predator exclusion pens. 
Appendix 9. Calculations used to determine pen loading densities for Social Security Pond based on $0.57 \mathrm{~m}^{3} / \mathrm{s}$ ( 20 c.f.s.) and release at $15.6 \mathrm{C}$ using recommended maximum hatchery pond loadings (Wedemeyer et al. 1981).

A. Turnover rate:

Pond capacity $=235,621 \mathrm{~m}^{3}$

Inflow $=2,039 \mathrm{~m}^{3} /$ hour

Turnover rate $=\left(235,621 \mathrm{~m}^{3}\right) /\left(2,039 \mathrm{~m}^{3} / \mathrm{h}\right)=115.56$ hours

B. Water movement through pond (unidirectional flow):

Length of pond $=457.2 \mathrm{~m}$

Water movement $=(4547.2 \mathrm{~m}) /(115.56 \mathrm{~h}) \times(60$ minutes $/ \mathrm{h})=0.066 \mathrm{~m} / \mathrm{hour}$

C. Pen exchange:

$1 /(0.066 \mathrm{~m} /$ minute $)=15.17$ minutes $/ \mathrm{m}$

$6.096 \mathrm{~m}$ (width of net-pen) $\mathrm{x} 15.17$ minutes $/ \mathrm{m}=92.48$ minutes to flow through net-pen

D. Rate of flow through net-pen:

79,296 1 (pen volume) $/ 92.48$ minutes $=857.441 /$ minute

E. Pen loading:

$$
===
$$

Weight of fish in high density pen at release $=90.72 \mathrm{~kg}$

$\mathrm{X}$ length (TL) of fish at release $\quad=87.1 \mathrm{~mm}$

Pen loading at SSP in high density pens, 1984:

$$
\begin{aligned}
& 90.72 \mathrm{~kg}=0.0012 \mathrm{~kg} / 1 \cdot \mathrm{min}^{-1} \cdot \mathrm{mm}^{-1} \\
& (857.44 \mathrm{1} / \mathrm{min})(87.5 \mathrm{~mm}) \quad============ \\
& \text { (or } 0.218 \mathrm{lb} \text { fish/g.min- }{ }^{1} \text {.inch- }{ }^{1} \text { ) }
\end{aligned}
$$


Appendix 10. Calculations used to determine pen loading densities for Rock Creek based on $0.57 \mathrm{~m}^{3} / \mathrm{s}$ (20 c.f.s.) and release at $15.6 \mathrm{C}$ using recommended maximum hatchery pond loadings (Wedemeyer et al. 1981).

A. Turnover rate:

Pond capacity $=1,252,123 \mathrm{~m}^{3}$

Inflow $=2,039 \mathrm{~m}^{3} /$ hour

Turnover rate $=\left(1,252,123 \mathrm{~m}^{3}\right) /\left(2,039 \mathrm{~m}^{3} / \mathrm{h}\right)=614.09$ hours

B. Water movement through backwater (unidirectional flow):

Length of backwater $=1810 \mathrm{~m}$

Water movement $=(1810 \mathrm{~m}) /(614.09 \mathrm{~h}) \times(60$ minutes $/ \mathrm{h})=0.049 \mathrm{~m} /$ minute

C. Pen exchange:

$1 /(0.049 \mathrm{~m} /$ minute $)=20.41$ minutes $/ \mathrm{m}$

$6.096 \mathrm{~m}$ (width of net-pen) $\times 20.41$ minutes $/ \mathrm{m}=124.42$ minutes to pass through net-pen

D. Rate of flow through net-pen:

79,296 1 (pen volume) $/ 124.42$ minutes $=637.331 /$ minute

E. Pen loading:

$$
==
$$

Weight of fish in high density pen at release $=90.72 \mathrm{~kg}$

$\mathrm{X}$ length (TL) of fish at release $\quad=87.1 \mathrm{~mm}$

Pen loading at RC in high density pens, 1984:

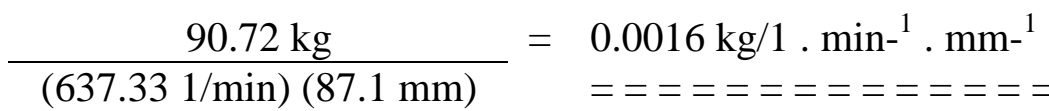

$$
\begin{aligned}
& \text { (or } 0.346 \mathrm{lb} \text { fish/g.min- }{ }^{1} \text {.inch- }{ }^{1} \text { ) }
\end{aligned}
$$


Appendix 11. Summary of two-way analysis of variance comparing mortality at different density-ration treatments at Social Security Pond and Rock Creek, 1984. A Newman-Keuls multiple comparison test was used to rank differences among the various pens. Underlined values are not significantly different at 0.05 .

Social Security Pond

ANOVA:

$\begin{array}{lllll}\text { Factor } & \text { df } & \text { SS } & \text { MS } & \mathrm{f} \\ \text { Date } & 6 & 70214 & 11702 & 32.5^{* *} \\ \text { Treatment } & 3 & 21038 & 7013 & 19.5^{* *} \\ \text { Date x Treatment } & 18 & 31422 & 1746 & 4.8^{* *} \\ \text { Error } & 28 & 10085 & 360 & \end{array}$

f $0.05(6,28)=2.454 ;$ f $0.05(3,28)=2.95 ;$ f $0.05(18,28)=1.99$;

Multiple Comparison of Treatments:

$\begin{array}{lllll}\begin{array}{l}\text { Mortality (fish/day) } \\ \text { (pen numbers) }\end{array} & 10.7 & 12.2 & 47.9 & 52.2 \\ & (5 \& 6) & (7 \& 8) & (1 \& 2) & (3 \& 4)\end{array}$

Rock Creek

ANOVA:

$\begin{array}{lllll}\text { Factor } & \text { df } & \text { SS } & \text { MS } & \mathrm{f} \\ \text { Date } & 4 & 4700 & 1175 & 31.9^{* *} \\ \text { Treatment } & 3 & 2725 & 908 & 24.7^{* *} \\ \text { Date x Treatment } & 12 & 3460 & 288 & 7.8^{* *} \\ \text { Error } & 20 & 737 & 37 & \end{array}$

f $0.05(4,20)=2.87 ;$ f $0.05(3,20)=3.10 ;$ f $0.05(12,20)=2.28$

Multiple Comparison of Treatments:

$\begin{array}{lllll}\begin{array}{l}\text { Mortality (fish/day) } \\ \text { (pen numbers) }\end{array} & 1.7 & 3.1 & 14.5 & 21.6 \\ & (5 \& 6) & (7 \& 8) & (3 \& 4) & (1 \& 2)\end{array}$


Appendix 12. Summary of 3-way ANOV (m observations/cell) using release weight ( $\mathrm{g}$ ) with feeding ration (F), density (D), and pen location (L; upstream or downstream) as primary factors for Social Security Pond and Rock Creek, 1984 $\left(\mathrm{F}_{(.05)} 1,353=3.86\right)$.

Social Security Pond

\begin{tabular}{llllll} 
Source of variation & d.f. & s.s & m.s. & $\mathrm{f}$ & \\
& & & & & \\
Feeding ration (F) & 1 & 34.7 & 34.7 & 21.9 & $* *$ \\
Density (D) & 1 & 12.7 & 12.7 & 8.0 & $* *$ \\
Pen location (L) & 1 & 4.9 & 4.9 & 3.1 & $\mathrm{~ns}$ \\
& & & & & \\
F x D & 1 & 2.9 & 2.9 & 1.8 & $\mathrm{~ns}$ \\
F x L & 1 & 12.0 & 12.0 & 7.6 & $* *$ \\
D x L & 1 & 0.7 & 0.7 & 0.4 & $\mathrm{~ns}$ \\
& & & & & \\
F x D x L & 1 & 3.1 & 3.1 & 2.0 & $\mathrm{~ns}$ \\
& & & & & \\
reek & & & & & \\
Source of variation & d.f. & s.s & m.s. & $\mathrm{f}$ & \\
& & & & & \\
Feeding ration (F) & 1 & 87.8 & 87.8 & 39.5 & $* *$ \\
Density (D) & 1 & 126.1 & 126.1 & 56.8 & $* *$ \\
Pen location (L) & 1 & 3.8 & 3.8 & 1.7 & $\mathrm{~ns}$ \\
& & & & & \\
F x D & 1 & 0.1 & 0.1 & $<0.1$ & $\mathrm{~ns}$ \\
F x L & 1 & 28.8 & 28.8 & 12.9 & $* *$ \\
D x L & 1 & 9.4 & 9.4 & 4.2 & $\mathrm{~ns}$ \\
& & & & & \\
F x D x L & 1 & 0.6 & 0.6 & 0.3 & $\mathrm{~ns}$ \\
\hline
\end{tabular}


Appendix 13. Results of one-way analysis of variance $(\mathrm{N}=45)$ and planned comparison test (Sokal \& Rholf 1981, pg. 234-235) comparing release weights of fed fish at Social Security Pond and Rock Creek with stock held at Spring Creek Hatchery (** - significant difference at 0.05).

Social Security Pond

$\begin{array}{llll}\text { ANOVA Table: } & \mathrm{df} & \text { MS } & \mathrm{f} \\ \text { Between groups } & 8 & 31.9 & 21.4^{* *} \\ \text { Within groups } & 396 & 1.5 & \\ \text { Total } & 404 & & \end{array}$

Planned Comparison:

(a) SS (control vs. treatments $)=\underline{(\Sigma \text { controls })^{2}}+\underline{=(\Sigma \text { treatments })^{2}-}$ $(\Sigma \text { controls \& treatments })^{2}=$

$\mathrm{n} n$

$$
\Sigma \mathrm{n}
$$

(b) $\frac{30,346}{45}+\frac{4,748,041}{360}-\frac{5,536,609}{405}=192$ (SS, or MS control vs. treatments)

(c) $\mathrm{F}_{\mathrm{s}}=\frac{\text { MS (control vs. treatments) }}{\text { within MS (from ANOVA table }}=\frac{192}{1.5}=128^{* *}$

$\mathrm{F} .05(1,396)={ }^{2.40}$

\section{Rock Creek}

$\begin{array}{llll}\text { ANOVA Table: } & \mathrm{df} & \text { MS } & \mathrm{f} \\ \text { Between groups } & 8 & 64.8 & 31.6^{* * *} \\ \text { Within groups } & 396 & 2.1 & \\ \text { Total } & 404 & & \end{array}$

Planned Comparison:

(a) SS (control vs. treatments $)=\frac{(\Sigma \text { controls })^{2}}{n}+\frac{=(\Sigma \text { treatments })^{2}-}{n}$ $(\Sigma \text { controls \& treatments })^{2}=$

$$
\Sigma \mathrm{n}
$$

(b) $\frac{30,346}{45}+\frac{5,428,900}{360}-\frac{6,270,016}{405}=271$ (SS, or MS control vs. treatments)

(c) $\mathrm{F}_{\mathrm{s}}=\frac{\mathrm{MS} \text { (control vs. treatments) }}{\text { within MS (from ANOVA table }}=\frac{271}{2.1}=129 * *$

$\mathrm{F} .05(1,396)={ }^{2.40}$ 
Appendix 14. Instantaneous growth rate $\left(G=\log _{e} W_{2}-\log _{e} W_{1} \times 1000\right)$ analysis using a oneway analysis of variance to determine difference over time among fed fish $\mathrm{F} .05$ $(3,31)=2.92)$.

\section{Social Security Pond}

\begin{tabular}{lllll} 
Source of variation & d.f. & s.s. & m.s. & $\mathrm{f}$ \\
$\quad$ Between groups & 3 & 15991 & 5330 & 14.55 \\
$\quad$ Within groups & 28 & 10259 & 366 & \\
Total & 31 & 26250 & & \\
Rock Creek & & & & \\
Source of variation & d.f. & s.s. & m.s. & $\mathrm{f}$ \\
$\quad$ Between groups & 3 & 7908 & 2636 & 44.92 \\
$\quad$ Within groups & 28 & 1643 & 59 & \\
Total & 31 & 9550 & & \\
& & & & \\
\hline
\end{tabular}




\section{SUMMARY OF EXPENDITURES FOR 1984}

1. Salaries

2. Travel and transportation

3. Equipment

Non-expendable

Expendable

4. Operation and maintenance

5. Overhead
75,677

16,492

60,021

46,414

535

49,375

$\$ 248,514$

Total 